\title{
24. LITHOLOGY, PETROGRAPHY, AND MINERALOGY OF BASALTS FROM DSDP SITES 482, 483, 484, AND 485 AT THE MOUTH OF THE GULF OF CALIFORNIA ${ }^{1}$
}

\author{
Brendon J. Griffin, Electron Optical Center, University of Adelaide, Box 498, G.P.O. Adelaide, South Australia 5001 \\ and \\ Rolf D. Neuser and Hans-Ulrich Schmincke, Institut für Mineralogie, Ruhr-Universität, 4630 Bochum, \\ Federal Republic of Germany
}

\begin{abstract}
The majority of the basalts drilled on Leg 65 in the Gulf of California are aphyric to sparsely phyric massive flows ranging in average thickness between 5 meters in the upper part of the sections in Holes 483 and $483 \mathrm{~B}$, where they are interlayered with sediment, and 14 meters in Hole $485 \mathrm{~A}$, where interlayered sediments constitute more than half of the section. Massive flows interlayered with pillows are generally less than 4 meters thick. The pillow lavas recovered are more phyric (up to 15 modal $\%$ ) and contain two to three generations of plagioclase and olivine \pm clinopyroxene. Plagioclase generally exceeds $60 \%$ of any given phenocryst assemblage. Resorbed olivine, clinopyroxene, and plagioclase megacrysts may reflect a high-pressure stage, the phenocrysts crystallizing in the main magma chamber and the skeletal microphenocrysts in dikes. Precise measurements of length/width ratios of different phenocryst types and compositions show low aspect ratios and large crystal volumes for early crystals and high ratios and low volumes for late crystals grown under strong undercooling conditions. The minerals examined show wide ranges in composition: in particular, plagioclase ranges from $\mathrm{An}_{92}$ to $\mathrm{An}_{36}$; clinopyroxene ranges from $\mathrm{Ca}_{41} \mathrm{Mg}_{51} \mathrm{Fe}_{8}$ in the cores of phenocrysts to $\mathrm{Ca}_{40}^{31}$ $\mathrm{Mg}_{45}^{49} \mathrm{Fe}_{15}^{20}$ in the groundmass; and olivine ranges from $\mathrm{Fo}_{86}$ to $\mathrm{Fo}_{81}$.

The wide range in mineral compositions, together with evidence of disequilibrium based on textures and comparisons of glass and mineral compositions, indicate complex crystallization histories involving both polybaric crystal fractionation and magma mixing.
\end{abstract}

\section{INTRODUCTION}

During Leg 65 of the Deep Sea Drilling Project (DSDP), six major holes were drilled at three principal sites $(482,483$, and 485$)$ at the mouth of the Gulf of California $\left(23^{\circ} \mathrm{N}\right)$ (Figs. 1 and 2), recovering a total of about 420 meters of basalt (Figs. 3 and 4). The holes were drilled in crust ranging in age from $0.5 \mathrm{~m} . \mathrm{y}$. (Site 482 ) to 2.0 m.y. (Site 483 ) at distances ranging from 12 $\mathrm{km}$ (Site 482 ) to $52 \mathrm{~km}$ (Site 483 ) from the spreading axis. One additional site (Site 484) was drilled in the nearby Tamayo Fracture Zone (Fig. 1). One of the main purposes of this leg was to study magma chamber evolution and crustal construction processes at a ridge with a moderately high spreading rate (about $5 \mathrm{~cm} / \mathrm{y}$.) in a young ocean basin with a high sediment influx for comparison with slow spreading ridges $(2-3 \mathrm{~cm} / \mathrm{y}$.) of the Atlantic type with very low sedimentation rates. The present chapter presents and briefly evaluates lithologic, petrographic, and mineral composition data for basalts from these sites. Major and trace element data are discussed in a companion paper (Flower et al., this volume) and volcaniclastic rocks and glass alteration are discussed by Schmincke (this volume). A fuller discussion of the data will be presented elsewhere.

\section{GENERAL LITHOLOGY}

Two principal types of basalt were recovered in the Leg 65 drill sites: massive basalt (Plate 1, Figs. 1-4; Plate 2,

\footnotetext{
1 Lewis, B. T. R., Robinson, P., et al., Init. Repts. DSDP, 65: Washington (U.S. Govt. Printing Office).
}

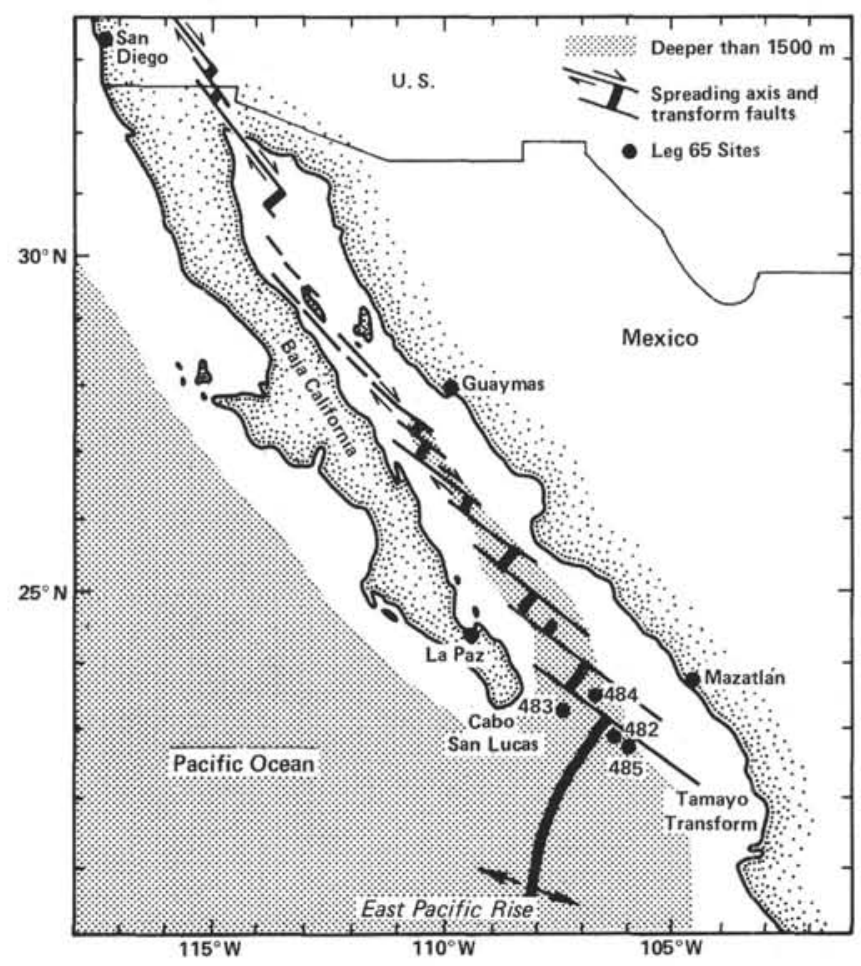

Figure 1. Index map of the Gulf of California showing the main sites drilled during Leg 65.

Figs. 1-3) and pillow basalt (Plate 2, Fig. 4; Fig. 5; Table 1). Most, if not all, of the massive basalts are believed to have been emplaced as sheet flows rather than as sills. This interpretation is based on several lines of evidence, 

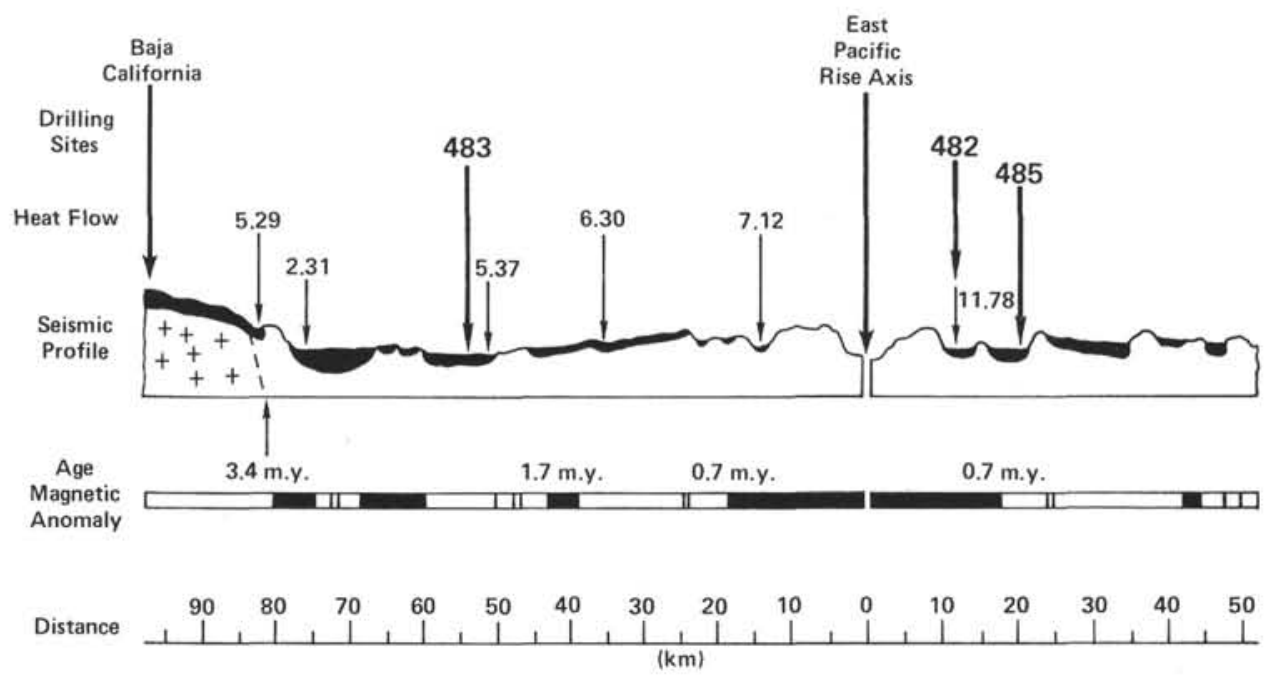

Figure 2. Cross section from Baja California through the East Pacific Rise showing main drill sites, sediment basins (black), heat-flow values, and magnetic anomalies. (Simplified from Lewis, this volume.)

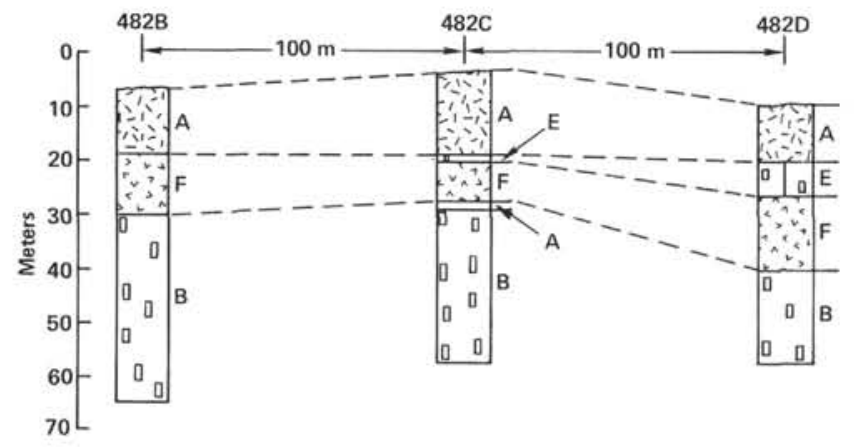

Figure 3. Stratigraphic correlation of main lithologic and chemical units between three holes drilled at Site 482. (A, B, E, and F represent chemical (or magma) types defined by Flower et al., this volume.)

including the following: (1) the presence of a distinctly vesicular zone below the top of the massive basalts (Plate 2, Figs. 1-3); (2) the absence of intrusive relationships; (3) the absence of baked contacts (the minor induration observed in the sediments immediately overlying several of the massive basalt units is attributed to subsequent diagenetic reactions near the sediment/basalt contact) (Plate 1, Figs. 1, 2); (4) the presence in one hole of a bedded hyaloclastite which chemically resembles the underlying massive basalt, suggesting derivation from the glassy crust of a surface flow (Schmincke, this volume); (5) the stratigraphic continuity over distances of several hundred meters of flows which are vertically separated from other massive units by a few centimeters to a few meters of sediment (Fig. 3); (6) the imprint of broken vesicles in the sediments lying in contact with the underlying basalt; and finally (7) the presence of ophimottled textures in the basalts themselves (Robinson et al., 1980).

Other lines of evidence, however, such as internal diking in Unit 3, Hole 483 (Plate 1, Fig. 4) and chemical differences within Unit 5, Hole 485 (Flower et al., this volume) suggest intrusive processes. In lithologic Unit 3
(Hole 483) the diking could have occurred as autointrusion during the sagging of a thick, liquid-cored lava sheet after it was emplaced on soft sediment. The chemical diversity within Lithologic Unit 5 (Hole 485A), however, is probably the result of the intrusion of magma batches of slightly differing chemistry. Thin stringers of sideromelane extending into the sediment from the top of Lithologic Unit 8 in Hole $485 \mathrm{~A}$ also suggest intrusion (Plate 1, Fig. 3). The sites drilled are thus intermediate between an environment with a high sedimentation rate, such as the Guaymas Basin, in which many if not all of the basalts are emplaced as intrusives (Curray, Moore, et al., in press) and one with a low sedimentation rate, such as the Mid-Atlantic Ridge, where nonintrusive sheet flows are common (e.g., Robinson et al., 1980). A further indirect but powerful argument for the interpretation of the massive basalts as extrusives is the succession of flows observed in Holes 483 and 483B in which massive flows of more evolved chemistry and mineralogy are underlain by pillow lavas of more mafic chemistry and higher phenocryst content (Flower et al., this volume). The massive basalt flows are from 3 to 7 meters thick in the upper part of Holes 483 and 483B above the pillows, but are much thicker in Hole 485A where the average thickness is about 10 to 14 meters (excluding Unit 5, which is $26 \mathrm{~m}$ thick). We are not certain whether thick sheet flows and intrusives grade into each other where surface flows have burrowed into soft sediments. In any case, thick massive flows appear to dominate during the late and probably waning stage of volcanism. They represent single extrusive events separated from each other by a significant hiatus in time. The sheet flows interbedded with pillow lavas in the lower part of Holes 483 and 483B (Fig. 4) are thinner and more vesicular than the flows higher in the section and are separated from each other and the overlying pillows by much thinner sediment layers. The pillow sequences are also thin (about $15 \mathrm{~m}$ ). Although sheet flow and pillow units could represent the distal edges of eruptive units, the similarity in the thickness of the units between Holes 

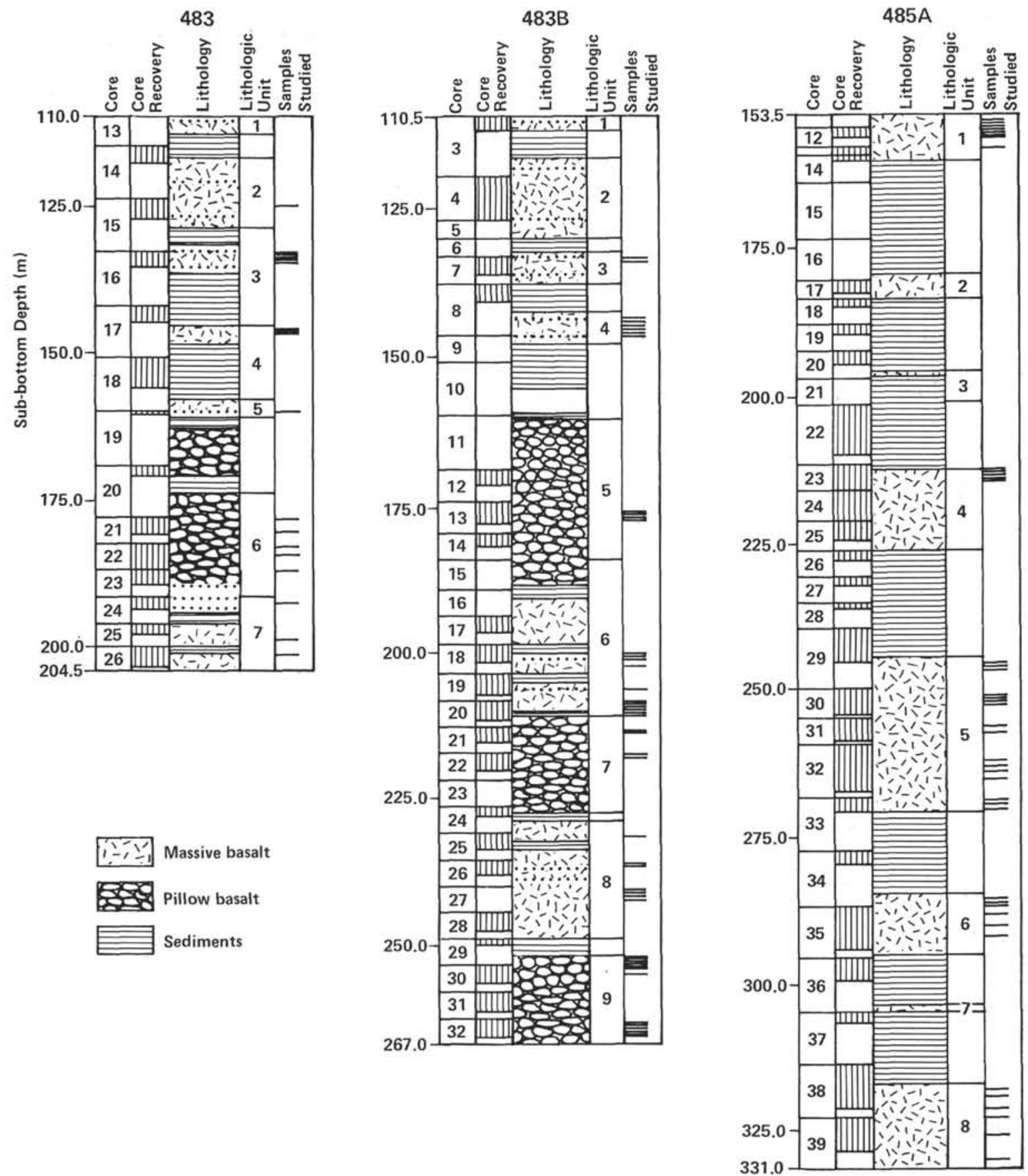

Figure 4. Stratigraphic columns for Holes 483, 483B, and 485A showing core recovery, main igneous lithologic units, and position of samples studied. Extent of igneous units defined by logs (Hole 483) and drilling rates (Hole 485A) is greater than recovered portion.

Table 1. Comparison of characteristic features of massive and pillow basalt flows drilled on Leg 65 .

\begin{tabular}{lccllll}
\hline \multicolumn{1}{c}{ Basalt } & $\begin{array}{c}\text { Thickness } \\
(\mathrm{m})\end{array}$ & $\begin{array}{c}\text { Pheno- } \\
\text { crysts } \\
(\text { vol. \%) }\end{array}$ & Contacts & $\begin{array}{c}\text { Thickness } \\
\text { of Glassy } \\
\text { Rinds } \\
(\mathrm{cm})\end{array}$ & Fractures \\
\hline $\begin{array}{l}\text { Massive (sheet) flows } \\
\text { Pillow (tube) flows }\end{array}$ & $\begin{array}{l}1.0-10.0 \\
0.4-0.5\end{array}$ & $5-15$ & $\begin{array}{l}\text { Flat } \\
\text { Curved }\end{array}$ & $\begin{array}{l}0.5 \\
1-2\end{array}$ & $\begin{array}{l}\text { Straight } \\
\text { Irregular }\end{array}$ \\
\hline
\end{tabular}

483 and 483B, about 100 meters apart (Fig. 4), as well as between Holes 482B, C, and D where the holes are about 200 meters apart (Fig. 3), suggests that the eruptive units are relatively thin in this environment. In other words, the height of sheet flow and pillow volcanoes during terminal activity at the mouth of the Gulf of California appears to have been low.

One of the factors determining volcano height appears to be spreading rate; volcano heights range from 
about 250 meters in the FAMOUS area to 50 meters in the Galapagos Rift (Ballard et al., 1979). Eruptive units, as well as eruptive cycles combining several petrologically related eruptive units, appear to be thicker in the Atlantic than in the Pacific, judging from the deepest holes drilled on Legs 37 and 51-53 (Flower and Robinson, 1979, 1981; Robinson et al., 1980).

Robinson et al. (1980) restrict the term "flow" to cooling units more than 3 meters thick. While such thicknesses hold for flows in the upper part of Holes 482, 483, 483B, and all of Hole 485A, several massive basalt units interlayered with pillows in the lower part of Holes 483 and 483B have been interpreted as flows even though they are less than three meters thick. We have observed flows of similar thickness to be common in the Troodos extrusive section (Schmincke et al., in press).

The reason why submarine lavas erupt as pillow and sheet flows is not clear, but high eruptive rates are thought to be an important factor (Ballard, 1979; Robinson et al., 1980). The lateral continuity of individual flows over at least 200 meters at two sites (482 and 483) also suggests that these flows represent high eruptive rates.

\section{PETROGRAPHY}

\section{METHODS}

About 60 thin sections, representing all holes and all major basalt types, were first examined qualitatively using a petrographic microscope. Twenty thin sections, chiefly of glassy to tachylitic basalts, were then studied quantitatively using the semi-automatic VIDEOPLAN picture-analysis system, which allows precise measurement of the volume, size, and form of phenocryst phases. Two methods of measuring crystal dimensions were employed in this study. In the first method, thin sections were projected onto a digitizing tablet and the phenocryst perimeters were then traced with an electronic pen. In the second method, the light from a light-emitting diode (LED) attached to an electronic cursor is projected into the measuring field of the microscope. Thus the movements of the cursor on the digitizing tablet can be followed while observing the thin section. The longest and shortest dimensions were then calculated for each crystal from the major (A) and minor (B) axes of the ellipse with the same moment of inertia as that of the measured grain. In each thin section, up to six areas about $0.8 \mathrm{~cm}$ in diameter were measured, covering from $50 \%$ to $80 \%$ of the area.

Pillow basalts were selected for more detailed examination in this study because they tend to be more phyric than massive basalts and because phenocrysts can be more easily identified in rocks with a glassy or fine-grained groundmass. The data from this analysis are reported in Table 2 and in Figures 5 through 9.

\section{General Petrographic Overview}

The basalts drilled on Leg 65 show the entire range of submarine basalt textures, from thick, fresh, glassy pillow rinds (Plate 2, Fig. 4) and thin, mostly devitrified margins of massive flows (Plate 1, Figs. 1, 2) to coarsegrained gabbros in the 10 - to 20 -meter-thick cooling units recovered at Site 485 . Most of the basalts are aphyric to sparsely phyric, but phyric basalts with $5 \%$ to $15 \%$ total phenocrysts are common in the pillowed units of Holes 483 and 483B (Table 2) and in the lowermost massive flows in Hole 483. Like most ocean floor basalts, the most common phenocryst phase is plagioclase, which generally composes from $60 \%$ to $90 \%$ of the phenocryst assemblage. Olivine is generally less abundant $(\leq 3 \%$ in volume), and clinopyroxene is usually sparse $(\leq 1 \%)$ to absent. Clinopyroxene is more common than olivine, however, in Cores 483B-22 through 25 , where it occurs principally in glomerophyric intergrowths with plagioclase, indicating more advanced crystallization of the magma prior to eruption.

Vesicles are rare to absent in the chilled margins examined but increase in size and abundance toward the interiors of pillows and the tops of sheet flows, averaging less than $2 \%$ by volume. Segregation vesicles, on the other hand, are very common in both types of basalt (Plate 2, Figs. 1-3). These become increasingly filled toward the interiors of pillows and may be rimmed with plagioclase.

Pervasive alteration is generally restricted to the filling of vesicles (Plate 2, Figs. 1-3) and fractures, and to the replacement with smectite of groundmass glass and most of the olivine in the more coarse-grained basalts. Higher-grade alteration occurs near a hydrothermal vein in Hole $482 \mathrm{C}$ and in the interior of several thick cooling units at Site 485 (Morrison and Thompson, this volume).

\section{Phenocrysts}

\section{Plagioclase}

Plagioclase occurs in four texturally and compositionally distinct forms in the Leg 65 basalts. These consist of megacrysts, normal phenocrysts, microphenocrysts, and microlites.

Plagioclase I (megacrysts): (Plate 3, Figs. 1, 2). The plagioclase megacrysts observed occur almost exclusively in the phyric pillow basalts of Holes 483 and 483B where they generally constitute less than $1 \%$ of the rock. They are classified as megacrysts not because of their abnormal size $(54 \mathrm{~mm})$ but because they are larger than the other plagioclase types, occur mostly as single crystals, are moderately to strongly rounded, may have cores filled with, or delineated by, devitrified melt inclusions, and show complex, in part oscillatory zoning with one or more major breaks in composition. The crystals vary in area from about 5 to $20 \mathrm{~mm}^{2}$ with a mean value of $10.5 \mathrm{~mm}^{2}$ and have an aspect ratio, $\mathrm{A} / \mathrm{B}$, which is always less than 3 (Figs. 6, 7).

Plagioclase II (normal phenocrysts): (Plate 3, Fig. 3). Normal phenocrysts constitute between $6 \%$ and $8 \%$ of the most phyric basalts and range in length from 0.1 to $0.3 \mathrm{~mm}$, with most averaging $0.7 \mathrm{~mm}$. The phenocrysts vary in area from 0.3 to $10 \mathrm{~mm}^{2}$ with a mean of $1.5 \mathrm{~mm}^{2}$ and have a maximum aspect ratio of 8 (Figs. 6 and 7). The crystals are invariably euhedral and commonly display synneusis twinning. Zoning, however, is not pronounced. The plagioclase in this group may occur in glomerocrysts with olivine but crystals intergrown with clinopyroxene are also included in this group, though they are mostly sub- to anhedral. In some basalts, phenocrysts grade irregularly into microphenocrysts.

Plagioclase III (microphenocrysts or pre-eruption microlites): Plate 3, Fig. 4; Plate 4, Fig. 1). The plagioclase crystals belonging to Group III are generally euhedral and range up to $1.2 \mathrm{~mm}$ in length, with most falling between 0.2 and $0.25 \mathrm{~mm}$ in length. The crystals are 
Table 2. Textures and phenocryst abundances in Leg 65 basalts.

\begin{tabular}{|c|c|c|c|c|c|c|c|c|c|c|c|c|c|c|c|c|c|c|}
\hline \multirow{2}{*}{$\begin{array}{c}\text { Sample } \\
\text { (interval in cm) }\end{array}$} & \multirow{2}{*}{$\begin{array}{l}\text { Rock } \\
\text { Type }\end{array}$} & \multirow{2}{*}{$\begin{array}{l}\text { Lithologic } \\
\text { Unit }\end{array}$} & \multirow{2}{*}{$\begin{array}{l}\text { Cooling } \\
\text { Unit }\end{array}$} & \multirow{2}{*}{$\begin{array}{c}\text { Chemical }^{\mathrm{a}} \\
\text { Type }\end{array}$} & \multicolumn{8}{|c|}{$\begin{array}{c}\text { Phenocrysts } \\
\text { (vol.\%, modal) }\end{array}$} & \multicolumn{3}{|c|}{$\begin{array}{l}\text { Glomerocrysts } \\
\text { (vol.\% modal) }\end{array}$} & \multirow[b]{2}{*}{ Vesicles } & \multirow{2}{*}{$\begin{array}{l}\text { Counted (C); } \\
\text { Estimated (E) }\end{array}$} & \multirow[b]{2}{*}{ Predominant Texture } \\
\hline & & & & & Ol I & OI II & Cpx 1 & Cpx II & PI I & Pl II & PI III & Total & $\mathrm{Ol}-\mathrm{Pl}$ & Ol-PI-Cpx & Pl-Cpx & & & \\
\hline \multicolumn{19}{|l|}{ Hole 482D } \\
\hline $11-1,24-28$ & PT & 3 & 7 & $\mathrm{~F}$ & - & 1.3 & - & - & - & 0.8 & 4.8 & 6.9 & d & & & 0.1 & c & Vitrophyric-variolitic \\
\hline \multicolumn{19}{|l|}{ Hole 483} \\
\hline $21-1,49-55$ & PT & 6 & 13 & $\mathrm{~F}$ & 0.2 & 1.2 & 0.6 & 0.1 & 0.3 & 6.5 & 2.1 & 11.0 & d & $\mathrm{m}$ & $\mathrm{m}$ & 0.3 & c & Variolitic with segregation vesicles \\
\hline $21-1,57-61$ & PC & 6 & 13 & $\mathrm{~F}$ & 0.3 & 0.9 & 0.2 & 0.1 & 1.0 & 5.5 & 2.4 & 10.4 & d & $\mathrm{m}$ & $\mathrm{m}$ & 0.6 & C & Tachylitic with segregation vesicles \\
\hline $21-1,78-82$ & PB & 6 & 13 & $\mathrm{~F}$ & 0.8 & 0.4 & - & 0.2 & 1.5 & 4.8 & 2.4 & 10.1 & d & $\mathrm{m}$ & $\mathrm{m}$ & 0.2 & c & Vitrophyric-tachylitic \\
\hline $21-3,6-9$ & PB & 6 & 17 & $\mathrm{~F}$ & 1.0 & 0.8 & - & 0.2 & 1.0 & 3.0 & 1.0 & 7.0 & d & & $\mathrm{m}$ & 0.1 & $\mathrm{E}$ & Vitrophyric-variolitic \\
\hline $21-2,68-72$ & PT & 6 & 23 & $\mathrm{~F}$ & 1.0 & 0.5 & 0.1 & - & 3.1 & 5.5 & 1.7 & 10.2 & $\mathrm{~m}$ & & d & 0.4 & c & Vitrophyric-tachylitic \\
\hline $22-2,85-88$ & PC & 6 & 23 & $\mathrm{~F}$ & 0.7 & 0.2 & - & 0.2 & 3.0 & 3.2 & 1.8 & 9.1 & $\mathrm{~m}$ & & d & 2.3 & c & Tachylitic with filled segregation vesicles \\
\hline $22-2,88-93$ & PC & 6 & 23 & F & 0.2 & 1.2 & 0.7 & 0.1 & 1.5 & 4.0 & 2.7 & 10.4 & $\mathrm{~m}$ & & d & 0.5 & c & Tachylitic with open segregation vesicles \\
\hline $22-2,94-99$ & PB & 6 & 23 & $\mathrm{~F}$ & 0.5 & 0.6 & 1.3 & - & 1.0 & 5.0 & 2.9 & 11.3 & $\mathrm{~m}$ & & d & 1.5 & c & Tachylitic with filled segregation vesicles \\
\hline \multicolumn{19}{|l|}{ Hole 483B } \\
\hline $20-2,37-42$ & SB & 6 & 26 & $\mathrm{H}$ & 0.3 & 0.5 & - & - & - & 1.5 & - & 2.3 & & & & 0.2 & $\mathrm{E}$ & Intergranular \\
\hline $20-2,50-59$ & SB & 6 & 26 & $\mathrm{H}$ & 0.3 & 0.7 & 0.2 & - & 0.4 & 1.6 & - & 3.2 & & & & 0.3 & E & Intergranular \\
\hline $20-2,62-65$ & SB & 6 & 26 & $\mathrm{H}$ & 4.0 & 0.5 & 0.3 & - & 1.0 & 1.2 & - & 7.0 & & & & - & E & Vitrophyric-intersertal \\
\hline $22-2,63-67$ & PC & 7 & 58 & $\mathrm{~J}$ & - & 1.0 & - & 3.0 & 1.0 & 6.0 & 1.0 & 12.0 & & & d & 0.5 & E & Tachylitic \\
\hline $22-2,77-82$ & PB & 7 & 58 & $\mathrm{~J}$ & - & 1.8 & - & 2.7 & 2.0 & 6.2 & 0.9 & 13.6 & $\mathrm{~m}$ & & d & 0.3 & $\mathrm{C}$ & Tachylitic-variolitic \\
\hline $25-2,39-45$ & ST & 8 & 78 & $\mathrm{~K}$ & - & 2.0 & - & 4.0 & 1.0 & 7.0 & 1.0 & 15.0 & & & d & 2.0 & $\mathrm{E}$ & Intersertal \\
\hline $27-1,12-18$ & ST & 8 & 83 & $\mathrm{~K}$ & - & 3.0 & - & 3.0 & 1.0 & 5.0 & 1.0 & 13.0 & & & d & 1.5 & E & Intersertal \\
\hline $30-3,13-16$ & PB & 9 & 94 & L & 1.0 & 2.0 & 0.1 & 1.0 & 2.5 & 4.0 & 1.0 & 11.6 & $\mathrm{~m}$ & & $\mathrm{~m}$ & 2.0 & E & Vitrophyric-variolitic \\
\hline $32-1,1-6$ & PT & 9 & 104 & M & 2.0 & 2.2 & - & 0.4 & 1.2 & 3.8 & 2.0 & 11.6 & d & & $\mathrm{m}$ & 1.0 & C & Vitrophyric-variolitic \\
\hline $32-1,27-31$ & PC & 9 & 104 & M & 1.5 & 3.2 & - & 0.4 & 1.1 & 2.6 & 2.1 & 10.9 & d & & $\mathrm{m}$ & 2.4 & c & Intersertal with segregation vesicles \\
\hline $32-1,44-50$ & PC & 9 & 104 & M & 1.4 & 1.1 & - & 0.4 & 1.5 & 5.2 & 2.3 & 11.9 & d & & $\mathrm{m}$ & 0.7 & c & Tachylitic \\
\hline $32-1,90-94$ & PB & 9 & 104 & $\mathrm{M}$ & 2.0 & 1.6 & - & tr & 1.2 & 3.9 & 2.8 & 12.5 & d & & & 1.0 & c & Variolitic \\
\hline \multicolumn{19}{|l|}{ Hole 485A } \\
\hline $11-3,57-60$ & PT & 1 & 1 & A & - & 3.3 & - & - & - & - & 0.7 & 4.0 & & & & 0.2 & C & Vitrophyric-variolitic \\
\hline $11-3,116-121$ & PC & 1 & 1 & A & - & 2.5 & - & - & - & - & 0.2 & 2.7 & & & & - & E & Intersertal \\
\hline $12-1,10-16$ & PC? & 1 & 2 & B & - & - & - & - & - & - & 2.7 & 2.7 & & & & - & C & Tachylitic-ophimottled \\
\hline $12-1,76-82$ & PC? & 1 & 3 & C & & & & & & & & & & & & & & Intersertal \\
\hline $13-1,110-117$ & SC & 1 & 5 & E & & & & & & & & & & & & & & Intersertal \\
\hline $30-3,38-41$ & SC & 5 & 9 & I & & & & & & & & & & & & & & Ophitic \\
\hline $30-4,8-13$ & $\mathrm{SC}$ & 5 & 9 & I & & & & & & & & & & & & & & Ophitic \\
\hline $36-3,65-69$ & PB? & 7 & 11 & $\mathrm{~K}$ & 0.3 & 1.2 & - & tr & 0.8 & 2.2 & 3.1 & 7.6 & d & & & - & C & Tachylitic-vitrophyric \\
\hline $39-1,26-32$ & $\mathrm{SC}$ & 8 & 12 & L & & & & & & & & & & & & & & Subophitic \\
\hline
\end{tabular}

Note: $\mathrm{PT}=$ pillow top; $\mathrm{PC}=$ pillow center; $\mathrm{PB}=$ pillow bottom; $\mathrm{ST}=$ sheet flow top; $\mathrm{SC}=$ sheet flow center; $\mathrm{SB}=$ sheet flow bottom; $\mathrm{d}=$ Dominant type of glomerocryst; $\mathrm{m}=$ Minor type of glomerocryst.
$\mathrm{After}$ Flower et al. (this volume). 


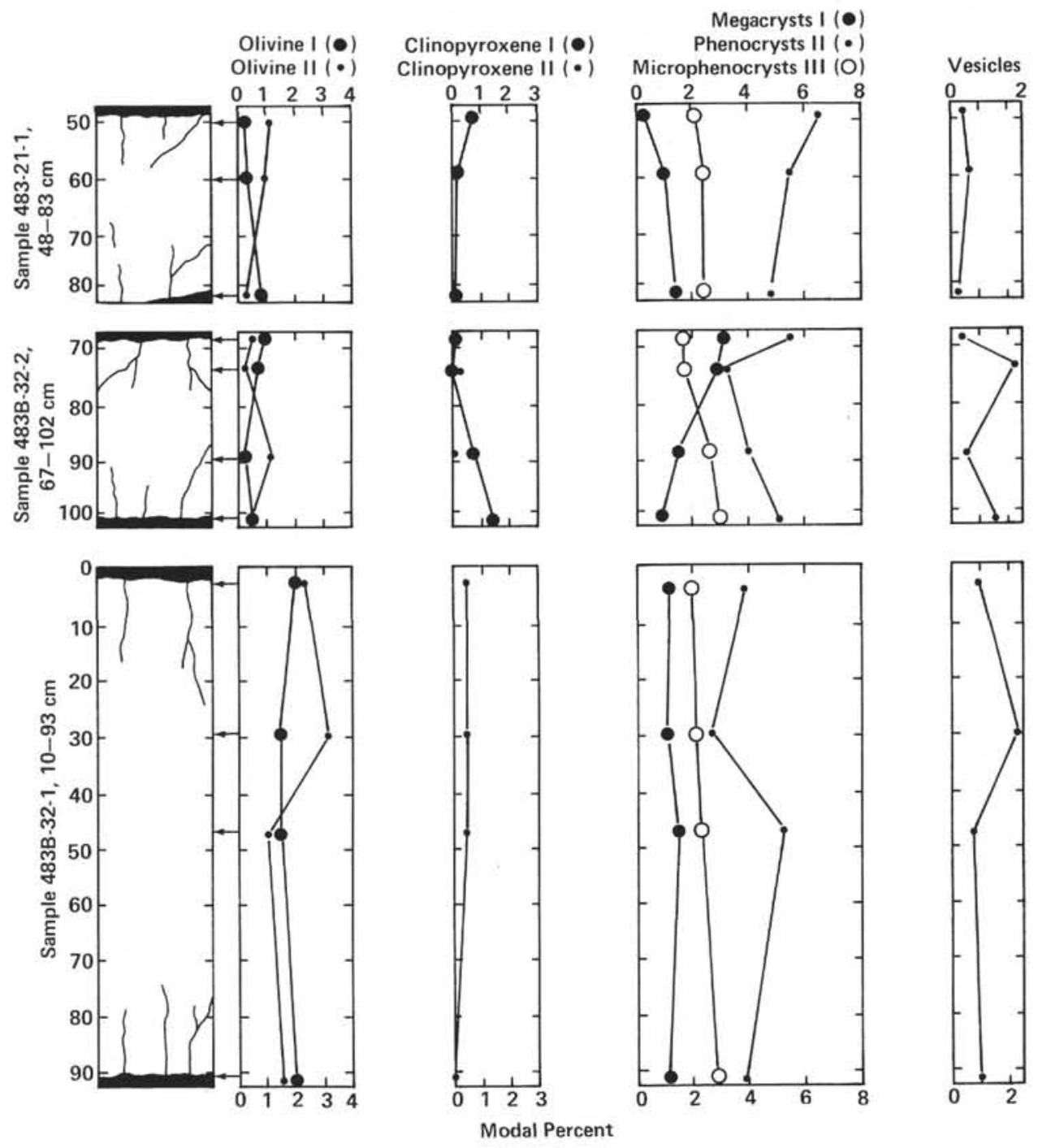

Figure 5. Modal variation of different generations of phenocrysts in three pillow lava units from Holes 483 and $483 \mathrm{~B}$.

usually acicular in form, with aspect ratios as high as 15 and areas ranging from 0.01 to $0.5 \mathrm{~mm}^{2}$, with a mean of less than $0.1 \mathrm{~mm}^{2}$ (Figs. 6 and 7). The plagioclase in this group occurs in varying amounts (generally less than $3 \%$ ) in the glassy selvages of pillows and flows; therefore, it must have crystallized prior to emplacement, even though its morphology is similar to that of microlites. In general it can be distinguished from groundmass plagioclase in the glassy or tachylitic rinds of pillows and flows, but not in the more slowly cooled interiors of the thicker cooling units.

Plagioclase IV (groundmass microlites): The plagioclase crystals belonging to Group IV resemble the microlites of Group III but show wide variations in texture and shape which depend principally on the cooling rate (Lofgren, 1974; Kirkpatrick, 1979; Natland, 1978; Kuo, 1980).

\section{Clinopyroxene}

Clinopyroxene occurs in three forms in the Leg 65 basalts. These consist of large isolated phenocrysts, small phenocrysts, and microphenocrysts and microlites.
Clinopyroxene I (normal phenocrysts): The phenocrysts in this group occur either as single, large $(\leq 2$ $\mathrm{mm}$ ), rounded crystals (Plate 4, Fig. 2) or in intergrowths with euhedral to subhedral plagioclase. The crystals are grass green in hand specimen and occur exclusively in the phyric pillow basalts of Holes 483 and 483B, where they constitute less than $1 \%$ of the rock.

Clinopyroxene II (phenocrysts and microphenocrysts): The crystals belonging to Group II are euhedral to anhedral and are generally about $0.5 \mathrm{~mm}$ in diameter. They occur chiefly in glomerocrysts with plagioclase (Plate 4, Figs. 3 and 4 ) and constitute less than $2 \%$ of the rock.

Clinopyroxene III (microlites): The clinopyroxene crystals belonging to Group III occur in all of the thicker cooling units drilled on the leg.

\section{Olivine}

Olivine occurs in three forms in the basalts recovered on Leg 65. These consist of megacrysts and phenocrysts, microphenocrysts, and groundmass crystals.

Olivine I (megacrysts and phenocrysts): The olivine megacrysts observed contain spinel inclusions, are slight- 


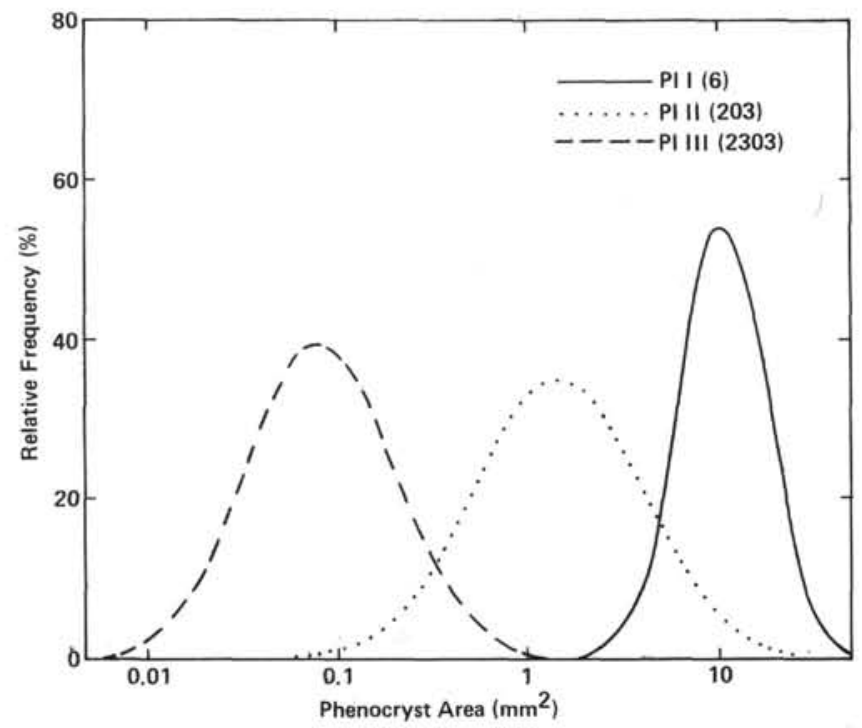

Figure 6. Relative frequency vs, cross-sectional area of phenocrysts belonging to different generations of plagioclase found in Leg 65 basalts. (PI I, megacrysts; PI II, phenocrysts; and PI III, microphenocrysts. Numbers in parentheses represent numbers of measurements.)

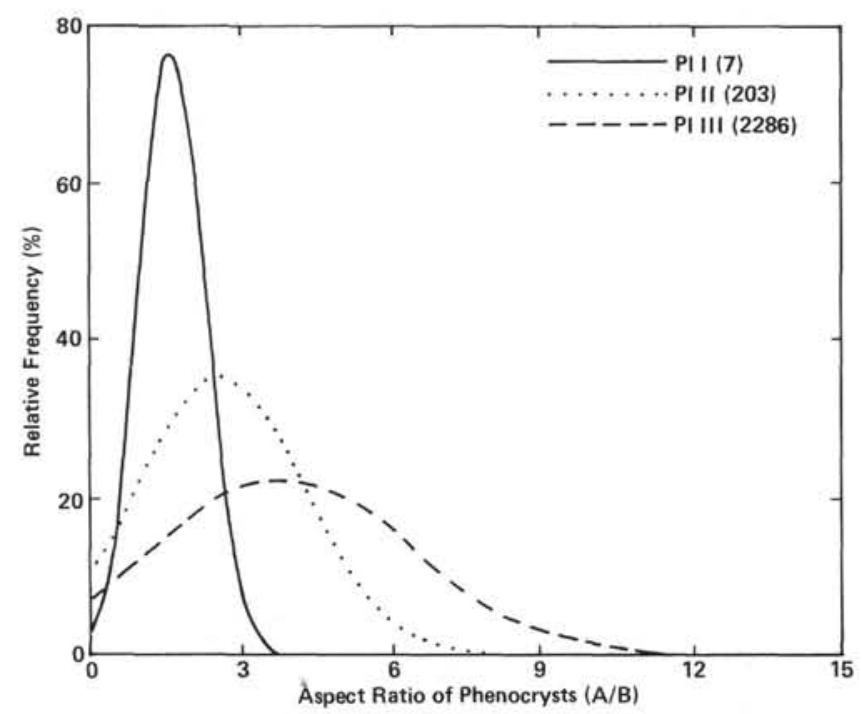

Figure 7. Relative frequency vs. aspect ratio of phenocrysts belonging to different generations of plagioclase found in Leg 65 basalts. (Pl I, megacrysts; PI II, phenocrysts; and PI III, microphenocrysts. The peaked distribution for Pl I indicates that the megacrysts generally have low length/width ratios while the flatness of the Pl III curve reflects the high length/width ratios of acicular plagioclase. The plagioclase phenocrysts (PI II) show an intermediate distribution of aspect ratios. Numbers in parentheses represent numbers of measurements.)

ly rounded, and occur as rare, single crystals up to 12 $\mathrm{mm}$ in length. The more common euhedral phenocrysts may be present in clots with plagioclase and, more rarely, with clinopyroxene phenocrysts.

Olivine II (microphenocrysts): The crystals belonging to Group II are generally less than $2 \mathrm{~mm}$ long, show skeletal growth forms (Plate 3, Fig. 4; Plate 4, Fig. 1)

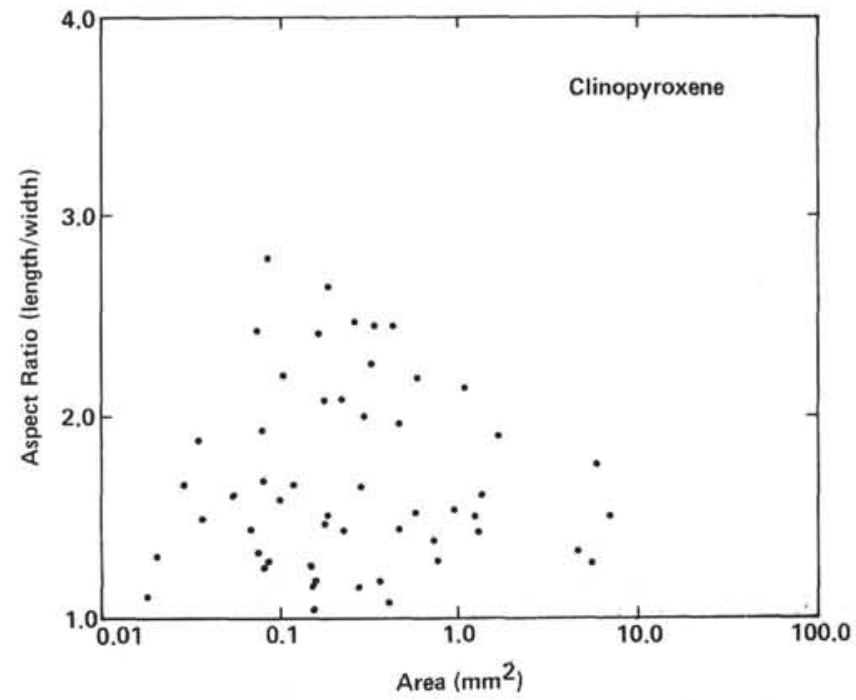

Figure 8. Aspect ratio vs. cross-sectional area of clinopyroxene crystals in Leg 65 basalts. (Note the relative abundance of small crystals with high length/width ratios. The low ratios shown for crystals with small areas result from crystals with long axes inclined to the plane of the thin section.)

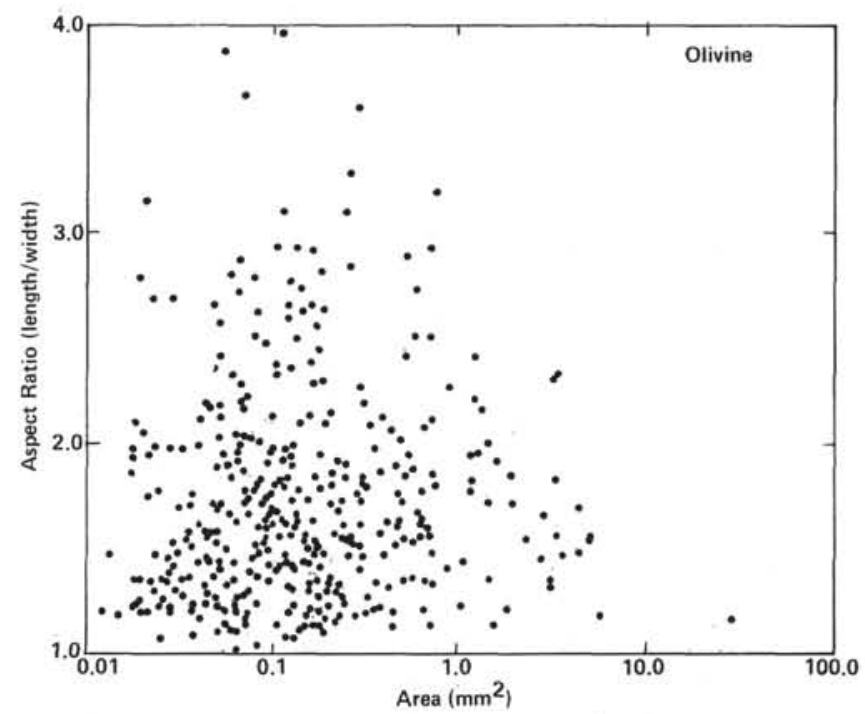

Figure 9. Aspect ratio vs. cross-sectional area of blivine crystals in Leg 65 basalts.

and occur in glomerophyric clots with plagioclase or, more rarely, as single crystals.

Olivine III (groundmass olivine): Groundmass olivine is common in the highly crystallized interiors of massive basalts, but it is generally replaced by alteration products.

\section{Plagioclase/Clinopyroxene Glomerophyric Clots}

Three types of plagioclase/clinopyroxene clots with gradations between all types are recognized in the Leg 65 basalts. These include: (1) small clots, generally 1.0 $\mathrm{mm}$ in length, of strained anhedral clinopyroxene and acicular plagioclase (Plate 4, Fig. 4); (2) intergrowths of moderately coarse-grained, subhedral to euhedral clino- 
pyroxene and plagioclase (Plate 4, Fig. 3), and rare clots of rounded clinopyroxene and plagioclase; and (3) subophitic to ophitic clots of anhedral clinopyroxene and plagioclase ranging up to $5 \mathrm{~mm}$ in length. These are distinct from the clinopyroxene/plagioclase clots that form in situ in the zone between the chilled margin and the fully crystallized interior of the thicker cooling units.

\section{Petrographic Relationships}

A number of conclusions may be drawn from the observations that have been presented. For example, it is clear that plagioclase phenocrysts are much more abundant in the Leg 65 basalts than are olivine and clinopyroxene phenocrysts but that a wide spectrum of assemblages is observed, including plagioclase + olivine, plagioclase + clinopyroxene, plagioclase + olivine + clinopyroxene, and olivine + spinel. It is also evident that each of the major phenocryst phases may appear in several different forms, such as megacrysts, normal phenocrysts, microphenocrysts, and microlites. Finally, it is apparent that the pillow units at Site 483 are distinctly more porphyritic than the massive basalts but that intracooling-unit variation in phenocryst volumes and proportions within the pillow basalts are negligible.

The occurrence of different assemblages and amounts of phenocrysts is clear evidence that crystal fractionation is likely to have played a major role in the evolution of these magmas. However, the diversity in textural types within a given rock indicates that single-stage, closed-system fractionation is not a realistic model for their generation. We interpret the phenocryst textures and different types of clots in terms of several different sites and dynamic conditions of crystallization. Of these, the cooling history appears to be the most important controlling factor. Crystals grown at slow cooling rates are larger and more equant (Figs. 7, 8), a physical relationship that is accentuated by the relatively high degree of resorption of these crystals occurring under disequilibrium conditions subsequent to their crystallization. Possible mechanisms for the resorption of early formed crystals include either a decrease in pressure accompanied by contraction of the primary plagioclase field or an influx of hot magma into a more evolved, cooler magma and the selective concentration of plagioclase as a result of flotation (see also Flower et al., this volume). The last generation of microphenocrysts, on the other hand, commonly displays a skeletal habit (Plate 4, Fig. 1 ), suggesting crystallization under rapid cooling conditions high in the section.

Apart from the high-pressure(?) megacrysts, the majority of phenocrysts are interpreted as having crystallized in the central magma chamber under the ridge. The occurrence of gabbroic clots indicates the disruption and incorporation of slowly cooled parts of the chamber into ascending magma. Although the phenocryst assemblages, amounts, and textures reflect a wide range in the degree of crystallization, the highly porphyritic varieties encountered in several holes in the Atlantic were not found, possibly indicating more rapid replenishment of the magma reservoirs.
The general lack of significant variation in phenocryst abundance within the pillows (Fig. 5) indicates the intrusion of well-mixed, homogeneous magmas. Even where such variation is significant, as in the base of several of the massive sheet flows in Hole 483B, it is interpreted as being the result of posteruptive crystal settling.

The more porphyritic nature of the pillows as a whole is not unique to Site 483 but has also been observed in several holes in the Atlantic. A systematic relationship is also suggested by the observation that thin sheet flows of a more fractionated, but related chemical composition underlie the pillow lavas (Flower et al., this volume). In such eruptive cycles, the sheet flows possibly represent the upper part of zoned magma chambers. Pillow sequences have also been observed to overiie sheet flows in the Galapagos Rift zone (Ballard, 1979) and a gradation toward more mafic composition is common in the eruptive cycles observed in the Atlantic (Flower and Robinson, 1979, 1981).

\section{GEOCHEMISTRY}

\section{SAMPLE SELECTION AND METHODS}

After the petrographic studies had been completed, 15 representative basalt samples were chosen for detailed microprobe studies of mineral composition and three additional samples were chosen for glass analysis. About 600 analyses were obtained on these samples at the Max-Planck Institute für Chemie in Mainz using a KEVEX 5100 energy dispersive analytical system attached to an ARL-SEMQ microprobe. An additional 80 analyses were obtained using an automated CAMEBAX microprobe. Glass analyses were carried out using a defocused beam. Particular attention was paid to compositional variations within single crystals. Representative mineral and glass analyses are given in Tables 3 through 9 , and the average mineral and glass compositions are summarized for selected basalt samples in Table 10.

\section{Mineral Chemistry}

\section{Olivine}

The olivine phenocrysts and microphenocrysts analyzed from Holes 483 and 483B are chemically homogeneous within each sample. The compositions range from $\mathrm{Fo}_{81.3}$ for the microphenocrysts examined in Section 483-21-3 to $\mathrm{Fo}_{86.2}$ for the phenocrysts in Section 483B30-3 (Table 3). These olivine crystals are neither in equilibrium (Roedder and Emslie, 1970) with the glass in the groundmass (where present) (Table 10), nor with possible "primary"' magma compositions. This indicates that at the time of olivine crystallization, these lavas had already undergone some degree of fractionation.

\section{Clinopyroxene}

Most of the clinopyroxenes examined consist of augite (Tables 4,5 ). The more primitive phenocryst cores fall in the endiopside field while the groundmass crystals range from endiopside toward ferroaugite and subcalcic augite in composition (Tables 4, 5; Fig. 10). The phenocryst core compositions are notably uniform in their major element chemistry $\left(100 \mathrm{Mg} / \mathrm{Mg}+\mathrm{Fe}^{2+}=84.86 ; \mathrm{Ca}_{41}\right.$ $\mathrm{Mg}_{51} \mathrm{Fe}_{8}$ ); in accordance with their relatively primitive major element chemistry, they contain minor $\mathrm{Cr}_{2} \mathrm{O}_{3}(1.0-$ $1.3 \%)$ and relatively little $\mathrm{TiO}_{2}(0.3 \%)$. 
Table 3. Composition of selected olivine phenocrysts.

\begin{tabular}{|c|c|c|c|c|c|c|c|c|c|c|c|c|}
\hline \multirow[b]{2}{*}{ Component } & & \multicolumn{2}{|c|}{$\begin{array}{c}\text { Sample } \\
\text { (interval in cm) }\end{array}$} & \multirow[b]{2}{*}{$\begin{array}{c}\text { 483B-30-3, } \\
18-22 \\
\text { (rim) }\end{array}$} & \multirow[b]{2}{*}{$\begin{array}{c}483 \mathrm{~B}-32-1 \\
1-6\end{array}$} & \multirow[b]{2}{*}{$\begin{array}{c}485 \mathrm{~A}-11-3 \\
68-73\end{array}$} & \multirow[b]{2}{*}{$\begin{array}{c}485 \mathrm{~A}-11-3 \\
68-73\end{array}$} & \multirow[b]{2}{*}{$\begin{array}{c}485 A-11-3, \\
116-121\end{array}$} \\
\hline & $\begin{array}{c}483-21-3 \\
6-9\end{array}$ & $\begin{array}{c}483-22-2 \\
85-88\end{array}$ & $\begin{array}{l}\text { 483B-22-1, } \\
26-32 \\
\text { (core) }\end{array}$ & $\begin{array}{c}483 \mathrm{~B}-22-1, \\
26-32\end{array}$ & $\begin{array}{c}\text { 483B-30-3, } \\
13-16 \\
\text { (core) }\end{array}$ & $\begin{array}{c}\text { 483B-30-3, } \\
13-16 \\
\text { (rim) }\end{array}$ & $\begin{array}{c}483 \mathrm{~B}-30-3, \\
18-22 \\
\text { (core) }\end{array}$ & & & & & \\
\hline \multicolumn{8}{|c|}{ Major oxide (wt. \%) } & & & & \\
\hline $\mathrm{SiO}_{2}$ & 39.29 & 39.78 & 39.24 & 39.29 & 40.44 & 39.42 & 41.18 & 40.61 & 39.60 & 40.87 & 39.61 & 38.64 \\
\hline $\mathrm{FeO}^{2} * \mathrm{a}$ & 17.57 & 15.73 & 17.65 & 17.76 & 12.87 & 16.99 & 12.25 & 15.45 & 15.05 & 12.88 & 17.53 & 11.80 \\
\hline $\mathrm{MnO}$ & 0.22 & 0.24 & 0.14 & 0.21 & 0.15 & - & 0.18 & 0.15 & - & 0.22 & 0.28 & 0.17 \\
\hline $\mathrm{MgO}$ & 42.41 & 44.11 & 42.47 & 42.06 & 46.85 & 43.48 & 47.34 & 45.11 & 44.44 & 46.56 & 42.81 & 48.62 \\
\hline $\mathrm{CaO}$ & 0.25 & 0.28 & 0.19 & 0.21 & 0.22 & 0.14 & 0.32 & 0.26 & 0.17 & 0.34 & 0.36 & 0.32 \\
\hline $\mathrm{NiO}$ & n.a. & 0.16 & n.a. & n.a. & 0.29 & n.a. & n.a. & n.a. & n.a. & n.a. & n.a. & 0.33 \\
\hline Total & 99.73 & 100.30 & 99.70 & 99.52 & 100.82 & 100.02 & 101.37 & 101.64 & 99.25 & 100.87 & 100.59 & 99.88 \\
\hline \multicolumn{8}{|c|}{ Cation proportions ${ }^{\mathrm{b}}$} & & & & & \\
\hline $\mathrm{Si}$ & 10.015 & 10.001 & 10.007 & 10.041 & 9.980 & 9.980 & 10.047 & 10.035 & 10.013 & 10.062 & 10.007 & 9.637 \\
\hline $\mathrm{Fe}$ & 3.744 & 3.308 & 3.763 & 3.796 & 2.657 & 3.596 & 2.498 & 3.193 & 3.181 & 2.652 & 3.704 & 2.461 \\
\hline Mn & 0.047 & 0.051 & 0.031 & 0.045 & 0.031 & - & 0.038 & 0.032 & - & 0.046 & 0.060 & 0.036 \\
\hline $\mathrm{Mg}$ & 16.112 & 16.531 & 16.140 & 16.020 & 17.235 & 16.407 & 17.214 & 16.616 & 16.748 & 17.089 & 16.124 & 18.077 \\
\hline $\mathrm{Ca}$ & 0.067 & 0.076 & 0.052 & 0.056 & 0.059 & 0.038 & 0.083 & 0.084 & 0.045 & 0.090 & 0.097 & 0.086 \\
\hline $\mathrm{Ni}$ & n.a. & 0.032 & n.a. & n.a. & 0.057 & n.a. & n.a. & n.a. & n.a. & n.a. & n.a. & 0.066 \\
\hline Total & 29.985 & 29.990 & 29.993 & 29.959 & 30.020 & 30.020 & 29.927 & 29.960 & 29.987 & 29.939 & 29.992 & 30.363 \\
\hline Fo $($ mole $\%)$ & 81.1 & 83.3 & 81.1 & 80.8 & 86.6 & 82.0 & 87.2 & 83.8 & 84.0 & 86.6 & 81.3 & 88.0 \\
\hline
\end{tabular}

a $\mathrm{FeO}^{*}$ represents total iron as $\mathrm{FeO}$.

b Proportions shown on a basis of 40 oxygen atoms.

\section{Plagioclase}

The plagioclase megacrysts, phenocrysts, and groundmass crystals studied vary widely in composition from $\mathrm{An}_{91.7}$ to $\mathrm{An}_{36.1}$ (Tables 6, 7; Fig. 11), the extent of differentiation varying according to the mode of occurrence. The phenocrysts and megacrysts display the highest values, the groundmass crystals display the lowest $\left(\mathrm{An}_{73-76}\right)$, and the crystals occurring in glomerocrysts $\left(\mathrm{An}_{75-61}\right)$ overlap with both. This overlap results in part from the difficulty of distinguishing microphenocrysts from coarse groundmass crystals.

The megacrysts and larger phenocrysts are characterized by strong optical zoning. To investigate the relationship between chemistry and zoning in these crystals, successive analyses were made from rim to rim and from core to rim across eight crystals at various intervals (40-200 $\mu \mathrm{m})$ depending on the crystal size. The most calcic phenocryst examined (Sample 485A-39-1, 26-32 cm) shows a uniform core $\left(\mathrm{An}_{91}\right)$ with a narrow, relatively sodic central zone $\left(\mathrm{An}_{80}\right)$ and an abrupt decrease in An content at the rims to groundmass values $\left(\mathrm{An}_{44}\right)$. Other calcic phenocrysts, however, show more systematic decreases in An content toward the rims (e.g., Sample 483B-20-2, 50-59 cm). Minor reversed zoning is also present. The less calcic phenocrysts $\left(\mathrm{An}_{70-80}\right)$ are more varied in their chemical zonation, with some being uniform (e.g., Sample 483-21-3, 6-9 cm) and others irregular (Sample 483-22-2, 85-88 cm). Interestingly, nearly all show asymmetric zonation.

\section{Clinopyroxene and Plagioclase Glomerocrysts}

The clinopyroxene/plagioclase glomerocrysts examined display a relatively restricted range of feldspar and clinopyroxene compositions $(\mathrm{An}=75-61 ; \mathrm{Mg}$ No. $=$ $85-77)$. These two parameters show a fairly positive covariant relationship with a correlation coefficient (for
14 samples) of 0.848 . This suggests that the glomerocrysts represent coliquidus phases from magmas having different degrees of evolution. However, such a linear relationship cannot be extrapolated to the most calcic plagioclase observed $\left(\mathrm{An}_{92}\right)$ because it would require the coexisting clinopyroxene to have a magnesium number exceeding 100 .

\section{DISCUSSION}

The phase chemistry that has been discussed demonstrates that the Leg 65 basalts are typical ocean floor basalts. The relatively low $\mathrm{Mg} / \mathrm{Mg}+\mathrm{Fe}$ values of the mafic minerals and glasses also suggest that the basalts are evolved, although it is difficult to determine the extent of this evolution. Petrographically, a crystallization sequence of plagioclase, plagioclase and clinopyroxene, and finally plagioclase, clinopyroxene, and olivine is recognized in the few samples analyzed by microprobe. This is supported by the phase chemistry: moderately evolved plagioclase $\left(\mathrm{An}_{75-61}\right)$ occurs with relatively magnesian clinopyroxene $(100 \mathrm{Mg} / \mathrm{Mg}+\mathrm{Fe}=85-77)$ in glomerocrysts, and magnesium-rich olivine $\left(\mathrm{Fo}_{86-81}\right)$ occurs with evolved plagioclase and clinopyroxene microphenocrysts ranging to that of the groundmass compositions.

The feldspar compositions range from strongly calcic $\left(\mathrm{An}_{92}\right)$ down to groundmass compositions both between grains and within strongly zoned crystals. These observations are in conflict with experimental studies of primitive ocean floor basalts that show that plagioclase more calcic than $\mathrm{An}_{80}$ does not exist as a liquidus phase (Green et al., 1979). The same authors, however, have suggested the existence of primary magmas with high $\mathrm{Al}_{2} \mathrm{O}_{3}$ contents, very low $\mathrm{Na}_{2} \mathrm{O} / \mathrm{CaO}$ ratios, and low $\mathrm{TiO}_{2}$ and $\mathrm{K}_{2} \mathrm{O}$ contents, which have segregated from Na-poor, $\mathrm{Ti}$ poor depleted peridotites at very shallow depths leaving a harzburgite residue. Such magmas would precipitate 
Table 4. Composition of selected clinopyroxene phenocrysts, Holes 483, 483B, and 485A.

\begin{tabular}{|c|c|c|c|c|c|c|c|c|c|c|c|}
\hline \multirow[b]{2}{*}{ Component } & \multicolumn{11}{|c|}{$\begin{array}{c}\text { Sample } \\
\text { (interval in } \mathrm{cm} \text { ) }\end{array}$} \\
\hline & $\begin{array}{c}483-21-3 \\
6-9\end{array}$ & $\begin{array}{c}483-21-3, \\
6-9\end{array}$ & $\begin{array}{c}\text { 483B-20-2, } \\
16-21 \\
\text { (rim) }\end{array}$ & $\begin{array}{c}483 \mathrm{~B}-20-2, \\
37-42 \\
\text { (core) }\end{array}$ & $\begin{array}{c}483 \mathrm{~B}-20-2, \\
37-42\end{array}$ & $\begin{array}{c}483 \mathrm{~B}-20-2 \\
37-42\end{array}$ & $\begin{array}{c}\text { 483B-20-2, } \\
50-59 \\
\text { (core) }\end{array}$ & $\begin{array}{c}\text { 483B-20-2 } \\
50-59 \\
\text { (rim) }\end{array}$ & $\begin{array}{c}483 \mathrm{~B}-20-2, \\
50-59\end{array}$ & $\begin{array}{c}\text { 483B-20-2, } \\
50-59 \\
\text { (core) }\end{array}$ & $\begin{array}{c}483 \mathrm{~B}-20-2, \\
50-59 \\
\text { (rim) }\end{array}$ \\
\hline \multicolumn{12}{|c|}{ Major oxide (wt.\%) } \\
\hline $\mathrm{SiO}_{2}$ & 53.93 & 51.66 & 53.69 & 53.57 & 53.57 & 50.02 & 52.01 & 50.96 & 52.96 & 53.07 & 49.65 \\
\hline $\mathrm{TiO}_{2}$ & 0.32 & 0.99 & 0.21 & 0.23 & 0.44 & 1.15 & 0,42 & 0.93 & 0.37 & 0.42 & 1.30 \\
\hline $\mathrm{Al}_{2} \mathrm{O}_{3}$ & 1.46 & 3.77 & 2.34 & 2.19 & 1.28 & 2.81 & 3.63 & 3.93 & 2.55 & 3.03 & 3.89 \\
\hline $\mathrm{FeO}^{* a}$ & 7.74 & 7.22 & 4.83 & 4.77 & 9.56 & 11.90 & 5.21 & 8.39 & 6.08 & 6.03 & 13.09 \\
\hline $\mathrm{MnO}$ & 0.13 & & & & 0.20 & 0.14 & & & & 17.50 & 0.17 \\
\hline $\mathrm{MgO}$ & 20.03 & 17.18 & 18.04 & 18.13 & 20.54 & 16.14 & 17.32 & 16.23 & 17.91 & 20.32 & 14.11 \\
\hline $\mathrm{CaO}$ & 16.32 & 19.46 & 21.14 & 20.58 & 14.34 & 16.10 & 19.99 & 19.10 & 19.64 & & 17.55 \\
\hline $\mathrm{Na}_{2} \mathrm{O}$ & & 0.14 & & 0.17 & & & 0.14 & & & & 0.30 \\
\hline $\mathrm{Cr}_{2} \mathrm{O}_{3}$ & 0.25 & 0.40 & 0.73 & 0.74 & 0.11 & & 1.30 & & 0.57 & 0.65 & \\
\hline Total & 100.18 & 100.81 & 100.98 & 100.38 & 100.02 & 98.26 & 100.01 & 99.53 & 100.09 & 101.03 & 100.05 \\
\hline \multicolumn{12}{|c|}{ Cation proportions ${ }^{\mathrm{b}}$} \\
\hline $\mathrm{Si}$ & 19.594 & 18.833 & 19.373 & 19.426 & 19.560 & 18.981 & 18.991 & 18.882 & 19.318 & 19.203 & 18.696 \\
\hline Al & 0.627 & 1.621 & 0.994 & 0.936 & 0.552 & 1.256 & 1.560 & 1.715 & 1.098 & 1.292 & 1.726 \\
\hline$\Sigma$ & 20.221 & 20.454 & 20.367 & 20.362 & 20.112 & 20.237 & 20.551 & 20.597 & 20.416 & 20.495 & 20.422 \\
\hline $\mathrm{Ti}$ & 0.088 & 0.272 & 0.058 & 0.062 & 0.120 & 0.329 & 0.116 & 0.260 & 0.102 & 0.115 & 0.367 \\
\hline $\mathrm{Fe}$ & 2.352 & 2.201 & 1.456 & 1.445 & 2.920 & 3.775 & 1.591 & 2.598 & 1.854 & 1.826 & 4.123 \\
\hline Mn & 0.039 & & & & 0.061 & 0.096 & & & & & 0.053 \\
\hline $\mathrm{Mg}$ & 10.845 & 2.334 & 9.704 & 9.797 & 11.177 & 9.131 & 9.424 & 8.963 & 9.739 & 9.440 & 7.919 \\
\hline $\mathrm{Ca}$ & 6.352 & 7.601 & 8.175 & 7.996 & 5.609 & 6.545 & 7.821 & 7.582 & 7.676 & 7.880 & 7.082 \\
\hline $\mathrm{Na}$ & & 0.099 & & 0.121 & & & 0.097 & & & & 0.217 \\
\hline $\mathrm{Cr}$ & 0.072 & 0.115 & 0.209 & 0.213 & 0.031 & & 0.375 & & 0.163 & 0.187 & \\
\hline$\Sigma$ & 19.747 & 19.622 & 19.601 & 19.635 & 19.917 & 19.825 & 19.189 & 19.403 & 19.534 & 19.447 & 19.760 \\
\hline Total & 39.968 & 40.076 & 39.968 & 39.997 & 40.029 & 40.062 & 39.98 & 40.000 & 39.950 & 39.942 & 40.182 \\
\hline Mg No. & 82.2 & 80.9 & 86.9 & 87.1 & 79.3 & 70.7 & 85.6 & 77.5 & 84.0 & 83.8 & 65.8 \\
\hline \multicolumn{12}{|c|}{ Normative composition } \\
\hline NAC & 0.00 & 0.98 & 0.00 & 1.21 & 0.00 & 0.00 & 0.97 & 0.00 & 0.00 & 0.00 & 0.00 \\
\hline Jd & 0.00 & 0.00 & 0.00 & 0.00 & 0.00 & 0.00 & 0.00 & 0.00 & 0.00 & 0.00 & 2.13 \\
\hline CCR & 0.72 & 0.16 & 2.02 & 0.92 & 0.31 & 0.00 & 2.79 & 0.00 & 1.64 & 1.88 & 0.00 \\
\hline CTi & 0.88 & 2.70 & 0.58 & 0.62 & 1.20 & 3.27 & 1.16 & 2.60 & 1.03 & 1.16 & 3.60 \\
\hline CATs & 1.90 & 5.27 & 3.40 & 3.60 & 1.40 & 2.97 & 5.26 & 5.97 & 3.67 & 4.40 & 3.81 \\
\hline Wo & 30.11 & 33.65 & 38.02 & 37.43 & 26.51 & 29.40 & 34.60 & 33.62 & 35.41 & 35.91 & 31.07 \\
\hline En & 54.39 & 46.32 & 48.68 & 48.99 & 55.72 & 45.37 & 47.24 & 44.81 & 48.94 & 47.47 & 38.88 \\
\hline Fs & 11.99 & 10.92 & 7.30 & 7.23 & 14.86 & 18.99 & 7.98 & 12.99 & 9.32 & 9.18 & 20.51 \\
\hline
\end{tabular}

Note: $\mathrm{NAC}=\mathrm{NaCr}\left(\mathrm{Si}_{2} \mathrm{O}_{6}\right) ; \mathrm{Jd}=\mathrm{NaAl}\left(\mathrm{Si}_{2} \mathrm{O}_{6}\right) ; \mathrm{CCR}=\mathrm{CaCr}\left(\mathrm{AlSiO}_{6}\right) ; \mathrm{CTi}=\mathrm{Tp}=\mathrm{CaTi}\left(\mathrm{Al}_{2} \mathrm{O}_{6}\right) ; \mathrm{CATs}=\mathrm{CaAl}\left(\mathrm{AlSiO}_{6}\right)$.

${ }^{a} \mathrm{FeO}^{*}$ represents total iron as $\mathrm{FeO}$.

b Proportions shown on a basis of 60 oxygen atoms.

the calcic plagioclase and magnesian clinopyroxene observed in ocean floor basalts. Such an origin requires magma mixing at oceanic spreading ridges. Rhodes and Dungan (1979) discuss this latter question in some detail based on residual glass compositions and compositional variations in olivine and plagioclase phenocrysts. They suggest that mixing and crystal contamination between upwelling primary magmas and evolved magmas in a steady-state magma chamber beneath the ridge give rise to a "buffered" ocean floor basalt magma. However, since none of the residual or included glass compositions match the composition suggested by Green et al. (1979) a primary magma origin is considered unlikely for the calcic phenocrysts considered in this study. It is also interesting to note that while Rhodes and Dungan (1979) found plagioclase values as high as $\mathrm{An}_{85}$ in liquidus runs on Leg 45 basalts, they did not find plagioclase as calcic as the natural phenocryst compositions.

The disparities observed between experimental work and natural rocks demonstrate the existence of a fundamental problem with respect to the petrogenesis of ocean floor basalt. Clearly an understanding of the genesis of highly calcic plagioclase phenocrysts is vital to determining the origin and evolution of ocean floor basalts. The Leg 65 results demonstrate the existence of a continuum of feldspar compositions to values as high as $\mathrm{An}_{92}$ within samples from one area. The presence of this compositional continuum is inconsistent with the existence of a uniform steady-state magma chamber since it demands wide variations in the conditions of crystallization. Since experimental studies on primitive basalts have failed to reproduce the range of phenocryst compositions seen in submarine basalts and studies of natural glass inclusions (Rhodes and Dungan, 1979) fail to support the existence of magmas other than those observed on the ocean floor, it is clear that the experimental results must be used with caution until the methodology of experimental petrology has been improved.

\section{ACKNOWLEDGMENTS}

We are grateful to the Deutsche Forschungsgemeinschaft for providing financial support for this research (Schm 250/24 and 26). We also wish to thank G. Pritchard for providing a number of mineral analyses; the Max Planck Institut für Kosmochemie (Mainz) and K. Abraham (Ruhr-Universität Bochum) for allowing us to use their 
Table 4. (Continued).

\begin{tabular}{|c|c|c|c|c|c|c|c|c|c|c|c|}
\hline \multicolumn{12}{|c|}{$\begin{array}{c}\text { Sample } \\
\text { (interval in cm) }\end{array}$} \\
\hline $\begin{array}{c}483 \mathrm{~B}-22-1, \\
28-32 \\
\text { (core) }\end{array}$ & $\begin{array}{c}483 \mathrm{~B}-22-1, \\
26-36\end{array}$ & $\begin{array}{c}\text { 483B-22-2, } \\
63-67\end{array}$ & $\begin{array}{c}483 \mathrm{~B}-22-2, \\
63-67\end{array}$ & $\begin{array}{c}\text { 483B-22-2, } \\
77-82\end{array}$ & $\begin{array}{c}483 \mathrm{~B}-22-2 \\
77-82\end{array}$ & $\begin{array}{c}483 \mathrm{~B}-25-2 \\
39-45\end{array}$ & $\begin{array}{c}483 \mathrm{~B}-25-2, \\
39-45 \\
\text { (core) }\end{array}$ & $\begin{array}{c}\text { 483B-25-2, } \\
39-45\end{array}$ & $\begin{array}{c}\text { 483B-27-1, } \\
12-18 \\
\text { (core) }\end{array}$ & $\begin{array}{c}483 \mathrm{~B}-30-3, \\
13-16\end{array}$ & $\begin{array}{c}\text { 483B-32-1, } \\
\text { I-6 } \\
\text { (core) }\end{array}$ \\
\hline 52.77 & 52.19 & 53.67 & 52.00 & 51.69 & 53.21 & 50.38 & 52.89 & 52.86 & 52.06 & 53.44 & 54.18 \\
\hline 0.42 & 0.95 & 0.25 & 0.51 & 0.84 & 0.47 & 1.44 & 0.47 & 0.31 & 0.55 & 0.42 & 0.25 \\
\hline 2.84 & 3.78 & 1.53 & 2.53 & 3.35 & 1.87 & 2.90 & 3.29 & 1.79 & 3.33 & 1.79 & 1.85 \\
\hline 6.15 & 7.17 & 6.33 & 8.55 & $\begin{array}{r}8.07 \\
0.75\end{array}$ & 7.08 & $\begin{array}{r}11.95 \\
0.94\end{array}$ & 6.27 & 8.91 & 6.15 & 6.83 & 6.23 \\
\hline 17.57 & 16.85 & 18.73 & 17.20 & $\begin{array}{r}0.25 \\
16.37\end{array}$ & $\begin{array}{r}0.20 \\
18.03\end{array}$ & $\begin{array}{r}0.24 \\
14.34\end{array}$ & 17.62 & 18.74 & 17.13 & 19.74 & \\
\hline 20.16 & 19.47 & 18.34 & 18.27 & 19.32 & 18.47 & 18.85 & 20.08 & 16.67 & 20.08 & 17.05 & 18.12 \\
\hline & & & & 0.28 & 0.22 & & & & 0.24 & & \\
\hline 0.61 & 0.28 & 0.33 & & & & & 0.70 & 0.11 & 0.67 & 0.60 & 0.77 \\
\hline 100.52 & 100.70 & 99.78 & 99.06 & 100.17 & 99.55 & 100.11 & 101.31 & 99.39 & 100.22 & 99.86 & 101.10 \\
\hline 19.207 & 19.002 & 19.615 & 19.305 & 19.038 & 19.538 & 18.912 & 19.101 & 19.491 & 19.038 & 19.459 & 19.477 \\
\hline 1.218 & 1.620 & 0.659 & 1.109 & 1.454 & 0.809 & 1.282 & 1.399 & 0.777 & 1.436 & 0.766 & 0.785 \\
\hline 20.425 & 20.622 & 20.274 & 20.414 & 20.492 & 20.347 & 20.194 & 20.500 & 20.268 & 20.474 & 20.225 & 20.262 \\
\hline 0.115 & 0.261 & 0.068 & 0.143 & 0.233 & 0.130 & 0.408 & 0.128 & 0.086 & 0.153 & 0.115 & 0.067 \\
\hline 1.872 & 2.184 & 2.118 & 2.655 & $\begin{array}{l}2.486 \\
0.078\end{array}$ & $\begin{array}{l}2.174 \\
0.062\end{array}$ & $\begin{array}{l}3.752 \\
0.077\end{array}$ & 1.893 & 2.747 & 1.882 & 2.079 & 1.873 \\
\hline 9.532 & 9.194 & 10.205 & 9.518 & 8.989 & 9.870 & 8.026 & 9.483 & 10.297 & 9.337 & & \\
\hline 7.863 & 7.583 & 7.181 & 7.268 & 7.624 & 7.266 & 7.583 & 7.768 & $\begin{array}{r}10.297 \\
6.587\end{array}$ & $\begin{array}{l}9.337 \\
7.870\end{array}$ & $\begin{array}{r}10.712 \\
6.653\end{array}$ & $\begin{array}{r}10.558 \\
6.977\end{array}$ \\
\hline & & & & 0.200 & 0.157 & & & $0.50 \%$ & 0.170 & 0.033 & 0.911 \\
\hline 0.176 & 0.082 & 0.095 & & & & & 0.200 & 0.032 & 0.193 & 0.173 & 0.219 \\
\hline 19.557 & 19.264 & 19.667 & 19.583 & 19.610 & 19.569 & 19.845 & 19.471 & 19.750 & 19.605 & 19.732 & 19.693 \\
\hline 39.982 & 39.886 & 39.941 & 39.997 & 40.102 & 40.006 & 40.039 & 39.971 & 40.018 & 40.079 & 39.957 & 39.955 \\
\hline 83.6 & 80.7 & 82.8 & 78.2 & 78.3 & 81.9 & 68.1 & 83.4 & 78.9 & 83.2 & 83.7 & 84.9 \\
\hline 0.00 & 0.00 & 0.00 & 0.00 & 0.00 & 0.00 & 0.00 & 0.00 & 0.00 & 1.69 & 0.00 & 0.00 \\
\hline 0.00 & 0.00 & 0.00 & 0.00 & 1.98 & 1.57 & 0.00 & 0.00 & 0.00 & 0.00 & 0.00 & 0.00 \\
\hline 1.78 & 0.83 & 0.96 & 0.00 & 0.00 & 0.00 & 0.00 & 2.01 & 0.32 & 0.23 & 1.74 & 2.20 \\
\hline 1.15 & 2.64 & 0.68 & 1.43 & 2.31 & 1.30 & 4.06 & 1.28 & 0.86 & 1.52 & 1.15 & 0.67 \\
\hline 4.07 & 5.14 & 2.15 & 4.12 & 3.90 & 1.96 & 2.32 & 4.73 & 2.86 & 5.49 & 1.82 & 2.17 \\
\hline 35.89 & 34.10 & 34.22 & 33.58 & 34.63 & 34.68 & 34.57 & 34.94 & 30.86 & 35.42 & 31.05 & 32.52 \\
\hline 47.78 & 46.25 & 51.33 & 47.60 & 44.49 & 49.32 & 39.97 & 47.55 & 51.39 & 46.32 & 53.79 & 53.03 \\
\hline 9.38 & 11.05 & 10.65 & 13.28 & 12.69 & 11.17 & 19.07 & 9.49 & 13.71 & 9.34 & 10.44 & 9.41 \\
\hline
\end{tabular}

microprobe facilities; A. Fischer and K. Bauszus for drafting and photography; and V. Helmke for typing the manuscript.

facilities; A. Fischer and K. Bauszus for drafting and photography; and $\mathrm{V}$. Helmke for typing the manuscript.

\section{REFERENCES}

Ballard, R. D., 1979. The Galapagos Rift at $86^{\circ} \mathrm{W}: 3$. Sheet flows, collapse pits, and lava lakes of the rift valley. J. Geophys. Res. $84: 5407-5422$.

Flower, M. F. J., and Robinson, P. T., 1979. Evolution of the FAMOUS ocean ridge segment: Evidence from submarine and deep sea drilling investigations. In Talwani, M., Harrison, C. G., and Hayes, D. E. (Eds.), Deep Drilling Results in the Atlantic Ocean: Ocean Crust. Sec. Maurice Ewing Series: Washington (Am. Geophys. Union), 314-330.

1981. Basement drilling in the western Atlantic Ocean 2. A synthesis of construction processes at the Cretaceous ridge axis. $J$. Geophys. Res., 86:6299-6309.

Green, D. H., Hibberson, W. O., and Jaques, A. L., 1979. Petrogenesis of Mid-ocean Ridge Basalts. In McElhinny, M. W. (Ed.), The Earth: Its Origin, Structure and Evolution: London (Academic Press) pp. 265-299.

Kirkpatrick, R. J., 1979. Processes of crystallization in pillow basalts, Hole 396B, DSDP Leg 46. In Dmitriev, L., Heirtzler, J., et al., In- it. Repts. DSDP, 46: Washington (U.S. Govt. Printing Office), 271-282.

Kuo, L.-C., 1980. Morphology and zoning patterns of plagioclase in phyric basalts from DSDP Legs 45 and 46, Mid-Atlantic Ridge [M.A. dissert.]. University of Illinois.

Lofgren, G., 1974. An experimental study of plagioclase crystal morphology: Isothermal crystallization. Am. J. Sci., 274:243-273.

Natland, J. H., 1978. Crystal morphologies in basalts from DSDP Site $395,23^{\circ} \mathrm{N}, 46^{\circ} \mathrm{W}$, Mid-Atlantic Ridge. In Melson, W. G., Rabinowitz, P. D., et al., Init. Repts. DSDP, 45: Washington (U.S. Govt. Printing Office), 423-445.

Rhodes, J. M., and Dungan, M. A., 1979. The evolution of oceanridge basaltic magma. Deep Drilling Results in the Atlantic Ocean: Ocean Crust. Sec. Maurice Ewing Series: Washington (Am. Geophys. Union), pp. 262-272.

Robinson, P. T., Flower, M. F. J., Swanson, D. A., et al., 1980. Lithology and eruptive stratigraphy of Cretaceous oceanic crust, western Atlantic Ocean. In Donnelly, T., Francheteau, J., Bryan, W., Robinson, P., Flower, M., Salisbury, M., et al., Init. Repts. DSDP, 51, 52, 53, Pt. 2: Washington (U.S. Govt. Printing Office), $1535-1556$.

Roedder, P. L., and Emslie, R. F., 1970. Olivine-liquid equilibrium. Contrib. Mineral. Petrol., 29:275-289.

Schmincke, H.-U., Rautenschlein, M., Robinson, P. T., and Mehegan, J., in press. Accretionary processes inferred from the Troodos Extrusive Series, Cyprus. Earth Planet. Sci. Lett. 
Table 4. (Continued).

\begin{tabular}{|c|c|c|c|c|c|c|c|c|c|c|c|}
\hline \multirow[b]{2}{*}{ Component } & \multicolumn{11}{|c|}{$\begin{array}{c}\text { Sample } \\
\text { (interval in } \mathrm{cm} \text { ) }\end{array}$} \\
\hline & $\begin{array}{c}\text { 483B-32-1, } \\
1-6 \\
\text { (rim) }\end{array}$ & $\begin{array}{c}\text { 483B-32-1, } \\
1-6 \\
\text { (core) }\end{array}$ & $\begin{array}{c}\text { 483B-32-1, } \\
1-6 \\
\text { (rim) }\end{array}$ & $\begin{array}{c}485 \mathrm{~A}-12-1 \\
76-82\end{array}$ & $\begin{array}{c}\text { 485A-13-1, } \\
110-117\end{array}$ & $\begin{array}{c}485 \mathrm{~A}-30-3, \\
38-41\end{array}$ & $\begin{array}{c}485 \mathrm{~A}-30-4 \\
8-13\end{array}$ & $\begin{array}{c}\text { 485A-30-4, } \\
8-13\end{array}$ & $\begin{array}{c}\text { 485A-30-4, } \\
8-13\end{array}$ & $\begin{array}{c}\text { 485A-39-1, } \\
26-32\end{array}$ & $\begin{array}{c}485 \mathrm{~A}-39-1, \\
26-32\end{array}$ \\
\hline \multicolumn{12}{|c|}{ Major oxide (wt. \%) } \\
\hline $\mathrm{SiO}_{2}$ & 51.67 & 51.71 & 51.51 & 51.02 & 52.02 & 52.80 & 53.03 & 53.86 & 51.78 & 50.75 & 52.47 \\
\hline $\mathrm{TiO}_{2}$ & 0.59 & 0.64 & 0.93 & 1.16 & 0.73 & 0.63 & 0.55 & 0.84 & 0.71 & 1.08 & 0.65 \\
\hline $\mathrm{Al}_{2} \mathrm{O}_{3}$ & 3.83 & 3.86 & 4.55 & 3.73 & 2.79 & 1.59 & 1.91 & 1.72 & 1.69 & 3.77 & 2.01 \\
\hline $\mathrm{FeO}^{*}$ *ă & 5.37 & 5.78 & 6.13 & 7.46 & 7.52 & 8.68 & 6.34 & 10.89 & 9.72 & 8.03 & 11.07 \\
\hline $\mathrm{MnO}$ & & & & 0.20 & 0.22 & 0.27 & 0.19 & 0.33 & 0.16 & & 0.27 \\
\hline $\mathrm{MgO}$ & 16.65 & 16.93 & 17.24 & 15.90 & 17.10 & 17.50 & 17.21 & 16.01 & 15.81 & 15.59 & 17.63 \\
\hline $\mathrm{CaO}$ & 20.89 & 20.26 & 20.03 & 19.93 & 18.76 & 17.79 & 20.28 & 18.04 & 18.75 & 20.38 & 16.46 \\
\hline $\mathrm{Na}_{2} \mathrm{O}$ & 0.28 & & 0.29 & 0.21 & 0.23 & 0.21 & 0.22 & 0.25 & & & \\
\hline $\mathrm{Cr}_{2} \mathrm{O}_{3}$ & 1.39 & 0.87 & 1.20 & & & & & & & 0.33 & \\
\hline Total & 100.68 & 100.05 & 101.89 & 99.64 & 99.37 & 99.46 & 99.73 & 101.94 & 98.62 & 99.94 & 100.49 \\
\hline \multicolumn{12}{|c|}{ Cation proportions ${ }^{\mathrm{b}}$} \\
\hline $\mathrm{Si}$ & 18.832 & 18.917 & 18.567 & 18.891 & 19.224 & 19.531 & 19.351 & 19.603 & 19.474 & 18.799 & 19.337 \\
\hline Al & 1.645 & 1.665 & 1.935 & 1.628 & 1.215 & 0.693 & 0.837 & 0.738 & 0.749 & 1.647 & 0.871 \\
\hline$\Sigma$ & 20.477 & 20.582 & 20.502 & 20.519 & 20.439 & 20.229 & 20.188 & 20.341 & 20.223 & 20.446 & 20.208 \\
\hline $\mathrm{Ti}$ & 0.162 & 0.176 & 0.253 & 0.323 & 0.203 & 0.175 & 0.154 & 0.230 & 0.201 & 0.302 & 0.181 \\
\hline $\mathrm{Fe}$ & 1.638 & 1.717 & 1.849 & 2.310 & 2.324 & 2.685 & 1.927 & 3.315 & 3.057 & 2.488 & 3.392 \\
\hline $\mathrm{Mn}$ & & & & 0.063 & 0.069 & 0.085 & 0.060 & 0.102 & 0.051 & & 0.084 \\
\hline $\mathrm{Mg}$ & 9.048 & 9.231 & 9.264 & 8.777 & 9.421 & 9.651 & 9.542 & 8.687 & 8.864 & 8.606 & 9.681 \\
\hline $\mathrm{Ca}$ & 8.158 & 7.942 & 7.734 & 7.960 & 7.428 & 7.051 & 8.081 & 7.035 & 7.555 & 8.088 & 6.501 \\
\hline $\mathrm{Na}$ & 0.197 & & 0.202 & 0.151 & 0.165 & 0.151 & 0.159 & 0.176 & & & \\
\hline $\mathrm{Cr}$ & 0.401 & 0.251 & 0.342 & & & & & & & 0.097 & \\
\hline$\Sigma$ & 19.604 & 19.367 & 19.644 & 19.584 & 19.610 & 19.798 & 19.923 & 19.545 & 19,728 & 19.581 & 19.839 \\
\hline Total & 40.081 & 39.949 & 40.146 & 40.103 & 40.049 & 40.022 & 40.111 & 39.886 & 39.951 & 40.027 & 40.047 \\
\hline Mg No. & 84.7 & 83.9 & 83.4 & 79.2 & 80.2 & 78.2 & 83.2 & 72.4 & 74.4 & 77.6 & 74.1 \\
\hline \multicolumn{12}{|c|}{ Normative composition } \\
\hline NAC & 1.95 & 0.00 & 1.99 & 0.00 & 0.00 & 0.00 & 0.00 & 0.00 & 0.00 & 0.00 & 0.00 \\
\hline Jd & 0.00 & 0.00 & 0.00 & 1.50 & 1.64 & 1.51 & 1.57 & 1.78 & 0.00 & 0.00 & 0.00 \\
\hline CCR & 2.02 & 2.52 & 1.38 & 0.00 & 0.00 & 0.00 & 0.00 & 0.00 & 0.00 & 0.97 & 0.00 \\
\hline $\mathrm{CTi}$ & 1.61 & 1.77 & 2.49 & 3.21 & 2,02 & 1.75 & 1.52 & 2.33 & 2.02 & 3.01 & 1.80 \\
\hline CATs & 5.54 & 5.34 & 6.35 & 4.12 & 3.20 & 0.96 & 1.83 & 0.52 & 1.74 & 4.72 & 2.53 \\
\hline Wo & 35.88 & 35.10 & 33.01 & 35.84 & 34.35 & 33.82 & 38.20 & 34.16 & 36.08 & 35.98 & 30.19 \\
\hline En & 44.88 & 46.39 & 45.66 & 43.56 & 46.88 & 48.15 & 47.08 & 43.94 & 44.54 & 42.91 & 48.18 \\
\hline Fs & 8.12 & 8.88 & 9.11 & 11.78 & 11.91 & 13.82 & 9.80 & 17.28 & 15.62 & 12.41 & 17.30 \\
\hline
\end{tabular}


Table 5. Composition of selected clinopyroxene groundmass crystals.

\begin{tabular}{|c|c|c|c|c|c|c|c|c|c|c|c|c|c|}
\hline \multirow[b]{2}{*}{ Component } & \multicolumn{13}{|c|}{$\begin{array}{c}\text { Sample } \\
\text { (interval in } \mathrm{cm} \text { ) }\end{array}$} \\
\hline & $\begin{array}{c}483 \mathrm{~B}-20-2 \\
16-21\end{array}$ & $\begin{array}{c}483 \mathrm{~B}-20-2 \\
16-21\end{array}$ & $\begin{array}{c}483 \mathrm{~B}-20-2 \\
50-59\end{array}$ & $\begin{array}{c}483 \mathrm{~B}-20-2 \\
50-59\end{array}$ & $\begin{array}{c}483 \mathrm{~B}-20-2 \\
50-59\end{array}$ & $\begin{array}{c}483 \mathrm{~B}-20-2 \\
50-59\end{array}$ & $\begin{array}{c}483 \mathrm{~B}-22-2 \\
63-67\end{array}$ & $\begin{array}{c}483 \mathrm{~B}-22-2, \\
63-67\end{array}$ & $\begin{array}{c}\text { 483B-27-1, } \\
12-18\end{array}$ & $\begin{array}{c}483 \mathrm{~B}-27-1, \\
12-18\end{array}$ & $\begin{array}{c}485 \mathrm{~A}-39-1 \\
26-32\end{array}$ & $\begin{array}{c}485 \mathrm{~A}-39-1 \\
26-32\end{array}$ & $\begin{array}{c}485 \mathrm{~A}-39-1, \\
26-32\end{array}$ \\
\hline \multicolumn{14}{|c|}{ Major Oxide (wt. $\%$ ) } \\
\hline $\mathrm{SiO}_{2}$ & 50.56 & 50.88 & 50.10 & 52.62 & 50.58 & 48.82 & 49.45 & 50.58 & 50.32 & 50.29 & 50.79 & 53.21 & 51.48 \\
\hline $\mathrm{TiO}_{2}^{2}$ & 1.15 & 1.23 & 1.15 & 0.68 & 1.26 & 2.18 & 1.43 & 1.18 & 1.06 & 1.44 & 0.88 & 1.46 & 1.02 \\
\hline $\mathrm{Al}_{2} \mathrm{O}_{3}$ & 2.02 & 2.52 & 4.37 & 3.24 & 3.05 & 5.67 & 4.77 & 3.55 & 2.10 & 3.99 & 2.81 & 1.28 & 1.89 \\
\hline $\mathrm{FeO}^{* a}$ & 15.57 & 13.38 & 8.37 & 6.29 & 14.49 & 11.46 & 8.84 & 10.36 & 15.01 & 10.20 & 9.14 & 11.35 & 15.07 \\
\hline $\mathrm{MnO}$ & 0.25 & 0.21 & & & 0.22 & 0.13 & 0.12 & 0.27 & 0.35 & & & 0.21 & 0.34 \\
\hline $\mathrm{MgO}$ & 12.74 & 15.64 & 16.89 & 17.67 & 14.33 & 19.98 & 15.61 & 17.77 & 14.30 & 15.09 & 16.23 & 18.08 & 15.64 \\
\hline $\mathrm{CaO}$ & 17.73 & 16.02 & 17.78 & 19.74 & 16.76 & 17.33 & 19.07 & 15.42 & 16.28 & 18.76 & 18.38 & 15.91 & 15.26 \\
\hline $\mathrm{Na}_{2} \mathrm{O}$ & & & 0.15 & 0.17 & & & 0.29 & & 0.27 & 0.22 & & & 0.17 \\
\hline $\mathrm{Cr}_{2} \mathrm{O}_{3}$ & & & 0.38 & 0.51 & & & 0.11 & 0.10 & & 0.21 & 0.35 & & \\
\hline Total & 100.0 & 99.88 & 99.18 & 100.93 & 100.69 & 100.58 & 99.68 & 99.23 & 99.69 & 100.20 & 98.60 & 100.50 & 100.87 \\
\hline \multicolumn{14}{|c|}{ Cation Proportions ${ }^{\mathrm{b}}$} \\
\hline $\mathrm{Si}$ & 19.246 & 19.093 & 18.616 & 19.075 & 18.960 & 18.133 & 18.420 & 18.823 & 19.131 & 18.697 & 19.067 & 19.582 & 19.239 \\
\hline Al & 0.906 & 1.113 & 1.916 & 1.383 & 1.346 & 2.482 & 2.094 & 1.557 & 0.941 & 1.749 & 1.244 & 0.555 & 0.831 \\
\hline$\Sigma$ & 20.152 & 20.206 & 20.532 & 20.458 & 20.306 & 20.615 & 20.514 & 20.380 & 20.072 & 20.446 & 20.311 & 20.137 & 20.070 \\
\hline $\mathrm{Ti}$ & 0.328 & 0.346 & 0.320 & 0.186 & 0.355 & 0.610 & 0.400 & 0.330 & 0.303 & 0.402 & 0.250 & 0.128 & 0.287 \\
\hline $\mathrm{Fe}$ & 4.957 & 4.200 & 2.601 & 1.908 & 4.541 & 3.558 & 2.753 & 3.223 & 4.773 & 3.170 & 2.869 & 3.494 & 4.710 \\
\hline $\mathrm{Mn}$ & 0.080 & 0.066 & & & 0.071 & 0.042 & 0.039 & 0.085 & 0.114 & & & 0.065 & 0.108 \\
\hline $\mathrm{Mg}$ & 7.227 & 8.745 & 9.354 & 9.546 & 8.007 & 8.295 & 8.666 & 9.856 & 8.103 & 8.361 & 9.083 & 9.916 & 8.713 \\
\hline $\mathrm{Ca}$ & 7.230 & 6.442 & 7.079 & 7.668 & 6.731 & 6.896 & 7.611 & 6.149 & 6.631 & 7.471 & 7.393 & 6.273 & 6.111 \\
\hline $\mathrm{Na}$ & & & 0.105 & 0.121 & & & 0.207 & & 0.196 & 0.162 & & & 0.120 \\
\hline $\mathrm{Cr}_{\mathrm{r}}$ & & & 0.112 & 0.146 & & & 0.031 & 0.031 & & 0.062 & 0.104 & & \\
\hline$\Sigma$ & 19.821 & 19.798 & 19.570 & 19.576 & 19.706 & 19.401 & 19.707 & 19.673 & 20.120 & 19.630 & 19.698 & 19.875 & 20.049 \\
\hline Total & 39.973 & 40.004 & 40.102 & 40.034 & 40.012 & 40.016 & 40.221 & 40.053 & 40.192 & 40.076 & 40.009 & 40.012 & 40.119 \\
\hline $\mathrm{Mg} \mathrm{No}$. & 59.3 & 67.6 & 78.2 & 83.3 & 63.8 & 70.0 & 75.9 & 74.4 & 62.9 & 72.5 & 76.0 & 73.9 & 64.9 \\
\hline \multicolumn{14}{|c|}{ Normative Composition } \\
\hline NAC & 0.00 & 0.00 & 1.04 & 1.21 & 0.00 & 0.00 & 0.30 & 0.00 & 0.00 & 0.62 & 0.00 & 0.00 & 0.00 \\
\hline JD & 0.00 & 0.00 & 0.00 & 0.00 & 0.00 & 0.00 & 1.72 & 0.00 & 1.92 & 0.99 & 0.00 & 0.00 & 1.19 \\
\hline CCR & 0.00 & 0.00 & 0.07 & 0.25 & 0.00 & 0.00 & 0.00 & 0.31 & 0.00 & 0.00 & 1.04 & 0.00 & 0.00 \\
\hline CTi & 3.29 & 3.46 & 3.17 & 1.85 & 3.55 & 6.09 & 3.91 & 3.28 & 2.97 & 3.99 & 2.50 & 1.28 & 2.84 \\
\hline CATs & 1.25 & 2.10 & 6.28 & 4.91 & 3.18 & 6.30 & 5.47 & 4.31 & 0.68 & 4.19 & 3.20 & 1.49 & 0.68 \\
\hline Wo & 33.98 & 29.41 & 30.28 & 34.70 & 30.26 & 28.23 & 32.54 & 26.63 & 30.70 & 32.98 & 33.56 & 29.94 & 28.44 \\
\hline En & 36.23 & 43.70 & 46.29 & 47.57 & 39.99 & 41.41 & 42.39 & 49.02 & 39.75 & 41.49 & 45.37 & 49.52 & 43.05 \\
\hline Fs & 25.25 & 21.32 & 12.87 & 9.51 & 23.03 & 17.97 & 13.66 & 16.45 & 23.97 & 15.73 & 14.33 & 17.77 & 23.81 \\
\hline
\end{tabular}

Note: $\left.\mathrm{NAC}=\mathrm{NaCr}\left(\mathrm{Si}_{2} \mathrm{O}_{6}\right) ; \mathrm{Jd}=\mathrm{NaAl}\left(\mathrm{Si}_{2} \mathrm{O}_{6}\right) ; \mathrm{CCR}=\mathrm{CaCR}\left(\mathrm{AlSiO}_{6}\right) ; \mathrm{CTi}=\mathrm{Tp}=\mathrm{CaTi}\left(\mathrm{Al}_{2} \mathrm{O}_{6}\right) ; \mathrm{CATs}=\mathrm{CaAl}(\mathrm{AlSiO})_{6}\right)$.

${ }^{a} \mathrm{FeO} *$ represents total iron as $\mathrm{FeO}$.

b Proportions shown on a basis of 60 oxygen atoms. 
Table 6. Composition of selected plagioclase phenocrysts, Holes 483, 483B, and 485A.

\begin{tabular}{|c|c|c|c|c|c|c|c|c|c|c|c|c|c|}
\hline \multirow[b]{2}{*}{ Component } & \multicolumn{13}{|c|}{$\begin{array}{c}\text { Sample } \\
\text { (interval in } \mathrm{cm} \text { ) }\end{array}$} \\
\hline & $\begin{array}{c}483-21-3, \\
6-9 \\
\text { (rim) }\end{array}$ & $\begin{array}{c}483-21-3 \\
6-9 \\
\text { (core) }\end{array}$ & $\begin{array}{c}483-21-3 \\
6-9 \\
\text { (core) }\end{array}$ & $\begin{array}{c}483 \mathrm{~B}-8-1 \\
24-27\end{array}$ & $\begin{array}{c}483 \mathrm{~B}-8-1 \\
24-27\end{array}$ & $\begin{array}{c}483 \mathrm{~B}-13-1, \\
60-64\end{array}$ & $\begin{array}{c}483 \mathrm{~B}-13-1, \\
60-64\end{array}$ & $\begin{array}{c}483 \mathrm{~B}-20-2 \\
16-21 \\
\text { (rim) }\end{array}$ & $\begin{array}{c}483 \mathrm{~B}-20-2 \\
16-21\end{array}$ & $\begin{array}{c}483 \mathrm{~B}-20-2 \\
16-21 \\
\text { (core) }\end{array}$ & $\begin{array}{c}\text { 483B-20-2, } \\
37-42 \\
\text { (core) }\end{array}$ & $\begin{array}{c}483 \mathrm{~B}-20-2 \\
37-42 \\
\text { (core) }\end{array}$ & $\begin{array}{c}483 \mathrm{~B}-20-2 \\
37-42 \\
\text { (ri:n) }\end{array}$ \\
\hline \multicolumn{14}{|c|}{ Major oxides (wt. $\alpha_{0}$ ) } \\
\hline $\begin{array}{l}\mathrm{SiO}_{2} \\
\mathrm{TiO}_{2}\end{array}$ & 48.15 & 52.44 & 49.69 & $\begin{array}{r}47.83 \\
0.04\end{array}$ & . 47.52 & $\begin{array}{r}48.03 \\
0.04\end{array}$ & $\begin{array}{r}49.35 \\
0.04\end{array}$ & 53.62 & 48.13 & 49.75 & 50.41 & 52.40 & 58.73 \\
\hline $\mathrm{Al}_{2} \mathrm{O}_{3}$ & 33.51 & 30.01 & 32.50 & 33.32 & 32.99 & 32.63 & 31.96 & 28.57 & 34.09 & 31.71 & 32.51 & 30.38 & 25.76 \\
\hline $\begin{array}{l}\mathrm{FeO} \cdot \mathrm{a} \\
\mathrm{MnO}\end{array}$ & 0.52 & 0.52 & 0.40 & 0.38 & 0.39 & $\begin{array}{l}0.52 \\
0.02\end{array}$ & $\begin{array}{l}0.52 \\
0.02\end{array}$ & 0.88 & 0.29 & 0.37 & 0.45 & 0.44 & 0.66 \\
\hline $\mathrm{MgO}$ & 0.18 & 0.25 & 0.24 & 0.18 & 0.17 & 0.17 & 0.11 & 0.27 & 0.17 & 0.13 & 0.26 & 0.30 & 0.16 \\
\hline $\mathrm{CaO}$ & 16.55 & 13.22 & 15.82 & 17.17 & 17.11 & 16.49 & 15.60 & 11.67 & 17.34 & 14.75 & 15.58 & 13.56 & 8.06 \\
\hline $\mathrm{Na}_{2} \mathrm{O}$ & 1.92 & 3.94 & 2.51 & 1.74 & 1.74 & 2.04 & 2.56 & 4.90 & 1.68 & 3.02 & 2.65 & 3.95 & 7.22 \\
\hline $\mathrm{K}_{2} \mathrm{O}$ & & 0.05 & 0.07 & & 0.01 & 0.01 & 0.01 & 0.08 & & & 0.06 & 0.06 & 0.12 \\
\hline Sro & & & & & & 0.04 & 0.06 & & & & & & \\
\hline Total & 100.82 & 100.42 & 101.24 & 100.66 & 99.96 & 99.99 & 100.21 & 100.00 & 101.69 & 99.73 & 101.92 & 101.08 & 100.71 \\
\hline \multicolumn{14}{|c|}{ Cation proportions ${ }^{\mathrm{b}}$} \\
\hline Si & 8.763 & 9.494 & 8.985 & 8.731 & 8.741 & 8.824 & 9.018 & 9.738 & 8.690 & 9.108 & 9.044 & 9.435 & 10.471 \\
\hline Al & 2.188 & 6.404 & 6.926 & 7.169 & 7.152 & 7.065 & 6.883 & 6.116 & 7.255 & 6.842 & 6.875 & 6.448 & 5.412 \\
\hline$\Sigma$ & 15.951 & 15.898 & 15.911 & 15.900 & 15.893 & 15.889 & 15.901 & 15.845 & 15.945 & 15.950 & 15.919 & 15.883 & 15.883 \\
\hline $\mathrm{Ti}$ & & & & 0.005 & & 0.006 & 0.005 & & & & & & \\
\hline $\mathrm{Fe}$ & 0.079 & 0.078 & 0.061 & 0.058 & 0.060 & 0.080 & 0.079 & 0.134 & 0.043 & 0.057 & 0.067 & 0.066 & 0.098 \\
\hline $\mathrm{Mn}$ & & & & & & 0.003 & 0.003 & & & & & & \\
\hline $\mathrm{Mg}$ & 0.049 & 0.067 & 0.066 & 0.049 & 0.047 & 0.047 & 0.030 & 0.073 & 0.046 & 0.035 & 0.069 & 0.080 & 0.043 \\
\hline $\mathrm{Ca}$ & 3.226 & 2.564 & 3.065 & 3.358 & 3.372 & 3.246 & 3.054 & 2.271 & 3.354 & 2.894 & 2.994 & 2.616 & 1.540 \\
\hline $\mathrm{Na}$ & 0.678 & 1.382 & 0.881 & 0.616 & 0.621 & 0.727 & 0.907 & 1.726 & 0.587 & 1.071 & 0.923 & 1.378 & 2.494 \\
\hline$K$ & & 0.012 & 0.017 & & 0.002 & 0.002 & 0.002 & 0.019 & & & 0.014 & 0.130 & 0.027 \\
\hline $\mathrm{Sr}$ & & & & & & 0.004 & 0.006 & & & & & & \\
\hline$\Sigma$ & 4.031 & 4.103 & 4.089 & 4.086 & 4.102 & 4.115 & 4.086 & 4.223 & 4.031 & 4.057 & 4.067 & 4.153 & 4.201 \\
\hline Total & 19.982 & 20.001 & 20.000 & 19.986 & 19.995 & 20.004 & 19.987 & 20.077 & 19.976 & 20.007 & 19.986 & 20.036 & 20.084 \\
\hline An(mole $\%)$ & 82.6 & 64.8 & 77.3 & 84.5 & 84.4 & 81.7 & 77.1 & 56.5 & 85.1 & 73.0 & 76.2 & 65.3 & 37.9 \\
\hline
\end{tabular}

a $\mathrm{FeO}$ represents total iron as $\mathrm{FeO}$,

b Proportions shown on a basis of 32 oxygen atoms.

Table 6. (Continued).

\begin{tabular}{|c|c|c|c|c|c|c|c|c|c|c|c|c|c|}
\hline \multirow[b]{2}{*}{ Component } & \multicolumn{13}{|c|}{$\begin{array}{l}\text { Sample } \\
\text { (interval in } \mathrm{cm} \text { ) }\end{array}$} \\
\hline & $\begin{array}{c}\text { 483B-25-2, } \\
39-45\end{array}$ & $\begin{array}{c}483 \mathrm{~B}-25-2, \\
39-45 \\
\text { (core) }\end{array}$ & $\begin{array}{c}483 \mathrm{~B}-25-2 \\
39-45\end{array}$ & $\begin{array}{c}483 \mathrm{~B}-27-1, \\
12-18\end{array}$ & $\begin{array}{c}\text { 483B-27-1, } \\
12-18\end{array}$ & $\begin{array}{c}483 \mathrm{~B}-27-1, \\
12-18\end{array}$ & $\begin{array}{c}483 \mathrm{~B}-30-3, \\
13-16 \\
\text { (core) }\end{array}$ & $\begin{array}{c}483 \mathrm{~B}-30-3, \\
13-16\end{array}$ & $\begin{array}{c}483 \mathrm{~B}-30-3, \\
13-16 \\
\text { (core) }\end{array}$ & $\begin{array}{c}\text { 483B-32-1, } \\
1-6\end{array}$ & $\begin{array}{c}\text { 483B-32-1, } \\
1-6 \\
\text { (core) }\end{array}$ & $\underset{1-6}{483 B-32-1}$ & $\begin{array}{c}\text { 483B-32-1, } \\
1-6 \\
\text { (rim) }\end{array}$ \\
\hline \multicolumn{14}{|c|}{ Major oxides (wt. $\%$ ) } \\
\hline $\begin{array}{l}\mathrm{SiO}_{2} \\
\mathrm{TiO}_{2}\end{array}$ & 55.49 & 48.77 & 52.06 & 50.15 & 48.22 & 52.20 & 46.33 & 51.61 & 48.62 & 51.99 & 47.26 & 48.63 & 53.67 \\
\hline $\mathrm{Al}_{2} \mathrm{O}_{3}$ & 27.46 & 31.54 & 30.21 & 31.19 & 32.53 & 30.35 & 33.89 & 30.48 & 32.64 & 30.17 & 33.29 & 32.34 & 28.86 \\
\hline $\begin{array}{l}\mathrm{FeO} * a \\
\mathrm{MnO}\end{array}$ & 0.87 & 0.32 & 0.49 & 0.41 & 0.31 & 0.54 & 0.33 & 0.59 & 0.21 & 0.56 & 0.32 & 0.31 & 0.83 \\
\hline $\mathrm{MgO}$ & 0.14 & 0.26 & 0.23 & 0.28 & 0.13 & 0.27 & 0.35 & 0.29 & 0.21 & 0.34 & 0.22 & 0.22 & 0.45 \\
\hline $\mathrm{CaO}$ & 10.26 & 15.14 & 13.37 & 14.60 & 15.91 & 13.46 & 17.54 & 13.84 & 15.99 & 13.59 & 17.16 & 15.77 & 12.49 \\
\hline $\mathrm{Na}_{2} \mathrm{O}$ & 5.70 & 2.67 & 3.88 & 3.04 & 2.09 & 3.84 & 1.25 & 3.66 & 2.36 & 3.71 & 1.53 & 2.25 & 4.55 \\
\hline $\begin{array}{l}\mathrm{K}_{2} \mathrm{O} \\
\mathrm{SrO}\end{array}$ & 0.09 & , & 0.06 & 0.06 & & 0.06 & & & & 0.10 & & & 0.18 \\
\hline Total & 100.04 & 98.70 & 100.30 & 99,72 & 99.19 & 100.63 & 99.69 & 100.45 & 100.03 & 100.45 & 99.79 & 99.53 & 101.02 \\
\hline \multicolumn{14}{|c|}{ Cation proportions ${ }^{\mathrm{b}}$} \\
\hline Si & 10.029 & 9.034 & 9.444 & 9.180 & 8.895 & 9.442 & 8.551 & 9.363 & 8.898 & 9.426 & 8.699 & 8.938 & 9.669 \\
\hline Al & 5.849 & 6.885 & 6.458 & 6.729 & 7.071 & 6.449 & 7.373 & 6.517 & 7.039 & 6.446 & 7.221 & 7.005 & 6.128 \\
\hline$\frac{\Sigma}{\mathrm{Ti}}$ & 15.878 & 15.919 & 15.902 & 15.90 & 15.966 & 15.891 & 15.924 & 15.880 & 15.937 & 15.872 & 15.920 & 15.943 & 15.797 \\
\hline $\begin{array}{l}\mathrm{Fe} \\
\mathrm{Mn}\end{array}$ & 0.135 & 0.050 & 0.074 & 0.063 & 0.048 & 0.082 & 0.051 & 0.089 & 0.032 & 0.085 & 0.049 & 0.048 & 0.125 \\
\hline $\mathrm{Mg}$ & 0.037 & 0.071 & 0.062 & 0.076 & 0.037 & 0.072 & 0.097 & 0.077 & 0.059 & 0.093 & 0.062 & 0.061 & 0.120 \\
\hline $\mathrm{Ca}$ & 1.987 & 3.004 & 2.599 & 2.863 & 3.144 & 2.608 & 3.469 & 2.689 & 3.135 & 2.639 & 3.385 & 3.105 & 2.411 \\
\hline $\mathrm{Na}$ & 1.996 & 0.959 & 1.365 & 1.078 & 0.748 & 1.346 & 0.448 & 1.287 & 0.838 & 1.302 & 0.547 & 0.802 & 1.589 \\
\hline $\begin{array}{l}\mathrm{K} \\
\mathrm{Sr}\end{array}$ & 0.022 & & 0.013 & 0.014 & & 0.015 & & & & 0.023 & & & 0.041 \\
\hline$\Sigma$ & 4.177 & 4.084 & 4.114 & 4.093 & 3.977 & 4.123 & 4.063 & 4.142 & 4.064 & 4.142 & 4.043 & 4.017 & 4.285 \\
\hline Total & 20.055 & 20.003 & 20.016 & 20.002 & 19.943 & 20.014 & 19.987 & 20.022 & 20.001 & 20.014 & 19.963 & 19.960 & 20.082 \\
\hline An (mole\%) & 49.6 & 75.8 & 65,4 & 72.4 & 80.8 & 65.7 & 88.6 & 67.6 & 78.9 & 66.6 & 86.1 & 79.5 & 59.7 \\
\hline
\end{tabular}


Table 6. (Continued).

\begin{tabular}{|c|c|c|c|c|c|c|c|c|c|c|c|c|c|c|}
\hline \multicolumn{15}{|c|}{$\begin{array}{c}\text { Sample } \\
\text { (interval in } \mathrm{cm} \text { ) }\end{array}$} \\
\hline $\begin{array}{c}483 \mathrm{~B}-20-2 . \\
50-59 \\
\text { (rim) }\end{array}$ & $\begin{array}{c}483 \mathrm{~B}-20-2, \\
50-59\end{array}$ & $\begin{array}{c}483 \mathrm{~B}-20-2, \\
50-59\end{array}$ & $\begin{array}{c}483 \mathrm{~B}-20-2 \\
50-59\end{array}$ & $\begin{array}{c}483 \mathrm{~B}-20-2, \\
50-59\end{array}$ & $\begin{array}{c}483 \mathrm{~B}-20-2 \\
50-59\end{array}$ & $\begin{array}{c}\text { 483B-20-2, } \\
50-59 \\
\text { (core) }\end{array}$ & $\begin{array}{c}\text { 483B-20-2, } \\
50-59 \\
\text { (rim) }\end{array}$ & $\begin{array}{c}\text { 483B-22-1, } \\
26-32 \\
\text { (rim) }\end{array}$ & $\begin{array}{c}483 \mathrm{~B}-22-1, \\
26-32\end{array}$ & $\begin{array}{c}483 \mathrm{~B}-22-1, \\
26-32\end{array}$ & $\begin{array}{c}483 \mathrm{~B}-22-2 \\
63-67 \\
\text { (rim) }\end{array}$ & $\begin{array}{c}483 \mathrm{~B}-22-2 \\
63-67\end{array}$ & $\begin{array}{c}483 \mathrm{~B}-22-2 \\
63-67 \\
\text { (core) }\end{array}$ & $\begin{array}{c}483 \mathrm{~B}-22-2 \\
77-82\end{array}$ \\
\hline 53.39 & 51.38 & 46.58 & 49.68 & 50.29 & 47.52 & 49.10 & 58.70 & 53.76 & 50.95 & 48.47 & 54.46 & 49.65 & 51.37 & $\begin{array}{r}52.14 \\
0.08\end{array}$ \\
\hline 29.41 & 30.42 & 33.59 & 32.42 & 31.57 & 33.04 & 32.40 & 25.33 & 28.49 & 30.06 & 31.92 & 29.10 & 31.85 & 30.54 & 29.57 \\
\hline 0.71 & 0.49 & 0.33 & 0.39 & 0.40 & 0.35 & 0.45 & 0.70 & 0.72 & 0.55 & 0.35 & 0.86 & 0.34 & 0.51 & $\begin{array}{l}0.70 \\
0.02\end{array}$ \\
\hline 0.25 & 0.30 & & & 0.27 & 0.24 & 0.20 & & 0.32 & 0.29 & 0.18 & 0.30 & 0.25 & 0.23 & 0.20 \\
\hline 12.56 & 13.83 & 17.09 & 15.41 & 14.96 & 16.62 & 15.94 & 7.63 & 11.98 & 13.50 & 15.43 & 12.25 & 15.26 & 13.85 & 13.64 \\
\hline 4.40 & 3.48 & 1.15 & 2.63 & 2.91 & 1.82 & 2.27 & 7.26 & 4.65 & 3.43 & 2.34 & 4.79 & 2.60 & 3.65 & 3.57 \\
\hline & & & & 0.06 & 0.06 & & 0.12 & 0.05 & 0.06 & 0.05 & 0.08 & 0.06 & 0.10 & $\begin{array}{l}0.01 \\
0.06\end{array}$ \\
\hline 100.72 & 99.90 & 98.73 & 100.53 & 100.45 & 99.65 & 100.36 & 99.74 & 99.98 & 98.84 & 98.74 & 101.85 & 100.02 & 100.23 & 99.99 \\
\hline 9.628 & 9.364 & 8.654 & 9.029 & 9.143 & 8.753 & 8.956 & 10.549 & 9.756 & 9.383 & 8.977 & 9.717 & 9.070 & 9.344 & 9.497 \\
\hline 6.521 & 6.533 & 7.354 & 6.945 & 6.766 & 7.174 & 6.965 & 5.366 & 6.093 & 6.525 & 6.969 & 6.119 & 6.857 & 6.547 & 6.348 \\
\hline 16.149 & 15.897 & 16.008 & 15.974 & 15.909 & 15.927 & 15.921 & 15.915 & 15.849 & 15.908 & 15.946 & 15.836 & 15.927 & 15.891 & $\begin{array}{r}15.845 \\
0.011\end{array}$ \\
\hline 0.107 & 0.075 & 0.052 & 0.059 & 0.061 & 0.053 & 0.068 & 0.105 & 0.109 & 0.085 & 0.054 & 0.128 & 0.051 & 0.077 & $\begin{array}{l}0.107 \\
0.003\end{array}$ \\
\hline 0.066 & 0.082 & & & 0.072 & 0.067 & 0.055 & & 0.087 & 0.079 & 0.050 & 0.081 & 0.069 & 0.061 & 0.054 \\
\hline 2.426 & 2.700 & 3.401 & 3.001 & 2.914 & 3.280 & 3.114 & 1.470 & 2.330 & 2.663 & 3.062 & 2.341 & 2.987 & 2.699 & 2.662 \\
\hline 1.540 & 1.231 & 0.413 & 0.927 & 1.026 & 0.649 & 0.805 & 2.528 & 1.636 & 1.224 & 0.839 & 1.656 & 0.919 & 1.286 & 1.261 \\
\hline & & & & 0.013 & 0.015 & & 0.028 & 0.012 & 0.014 & 0.013 & 0.019 & 0.014 & 0.023 & $\begin{array}{l}0.002 \\
0.006\end{array}$ \\
\hline 3.68 & 4.088 & 3.867 & 3.987 & 4.085 & 4.064 & 4.043 & 4.131 & 4,173 & 4.065 & 4.018 & 4.225 & 4.041 & 4.143 & 4.006 \\
\hline 20.017 & 19.985 & 19.875 & 19.961 & 19.994 & 19.991 & 19.964 & 20.046 & 20.022 & 19.973 & 19.964 & 20.061 & 19.968 & 20.034 & 19.951 \\
\hline 61.2 & 68.7 & 89.2 & 76.4 & 73.7 & 83.2 & 79.5 & 36.5 & 58.6 & 68.3 & 78.2 & 58.3 & 76.2 & 67.3 & 67.8 \\
\hline
\end{tabular}

Table 6. (Continued).

\begin{tabular}{|c|c|c|c|c|c|c|c|c|c|c|c|c|c|}
\hline \multicolumn{14}{|c|}{$\begin{array}{c}\text { Sample } \\
\text { (interval in cm) }\end{array}$} \\
\hline $\begin{array}{c}485 \mathrm{~A}-11-3, \\
68-73\end{array}$ & $\begin{array}{c}485 \mathrm{~A}-12-1, \\
76-82\end{array}$ & $\begin{array}{c}\text { 485A-13-1, } \\
110-117\end{array}$ & $\begin{array}{l}\text { 485A-13-1, } \\
110-117\end{array}$ & $\begin{array}{c}485 \mathrm{~A}-30-3 \\
38-41\end{array}$ & $\begin{array}{c}485 \mathrm{~A}-30-4 \\
8-13\end{array}$ & $\begin{array}{c}485 \mathrm{~A}-30-4 \\
8-13\end{array}$ & $\begin{array}{c}485 \mathrm{~A}-30-4 \\
8-13\end{array}$ & $\begin{array}{c}485 \mathrm{~A}-39-1 \\
26-32\end{array}$ & $\begin{array}{c}485 \mathrm{~A}-39-1 \\
26-32\end{array}$ & $\begin{array}{c}\text { 485A-39-1, } \\
26-32 \\
\text { (core) }\end{array}$ & $\begin{array}{c}485 \mathrm{~A}-39-1, \\
26-32 \\
\text { (rim) }\end{array}$ & $\begin{array}{c}485 \mathrm{~A}-39-1 \\
26-32\end{array}$ & $\begin{array}{c}485 \mathrm{~A}-39-1 \\
26-32\end{array}$ \\
\hline 50.16 & 51.82 & 51.87 & 56.15 & 52.06 & 53.34 & 51.22 & 50.11 & 50.89 & 57.06 & 45.38 & 53.71 & 48.69 & 53.36 \\
\hline 0.08 & 0.08 & 0.06 & 0.15 & 0.06 & 0.11 & 0.06 & & & & & & & \\
\hline 31.08 & 29.55 & 30.07 & 27.12 & 29.08 & 29.01 & 30.16 & 29.83 & 30.85 & 26.56 & 34.66 & 28.97 & 32.71 & 29.16 \\
\hline 0.59 & 0.67 & 0.63 & 1.10 & 0.72 & 0.76 & 0.60 & 0.55 & 0.45 & 0.62 & 0.26 & 0.80 & 0.37 & 0.67 \\
\hline & 0.02 & 0.02 & 0.02 & & 0.03 & 0.02 & & & & & & & \\
\hline 0.20 & 0.25 & 0.18 & 0.11 & 0.09 & 0.22 & 0.17 & & 0.28 & 0.11 & 0.18 & 0.19 & 0.24 & 0.22 \\
\hline 15.09 & 13.87 & 14.24 & 11.06 & 13.90 & 12.79 & 14.14 & 14.46 & 14.19 & 9.28 & 18.27 & 12.12 & 16.17 & 12.34 \\
\hline 3.04 & 3.69 & 3.46 & 5.36 & 3.85 & 4.32 & 3.57 & 2.74 & 3.34 & 6.44 & 0.99 & 4.69 & 2.14 & 4.63 \\
\hline & 0.01 & & 0.01 & 0.01 & 0.02 & 0.02 & & & & & & & 0.05 \\
\hline 0.04 & 0.06 & 0.07 & 0.06 & & 0.07 & 0.06 & & & & & & & \\
\hline 100.28 & 100.02 & 100.60 & 101.14 & 99.77 & 100.67 & 100.02 & 97.69 & 100.0 & 100.07 & 99.74 & 100.49 & 100.32 & 100.43 \\
\hline 9.156 & $9.4 \dot{\delta} 2$ & 9.407 & 10.057 & 9.520 & 9.640 & 9.351 & 9.346 & 9.276 & 10.261 & 8.391 & 9.704 & 8.890 & 9.652 \\
\hline 6.686 & 6.353 & 6.427 & 5.725 & 6.268 & 6.179 & 6.490 & 6.558 & 6.628 & 5.629 & 7.553 & 6.169 & 7.037 & 6.217 \\
\hline 15.842 & 15.805 & 15.834 & 15.782 & 15.788 & 15.819 & 15.841 & 15.904 & 15.904 & 15.890 & 15.944 & 15.873 & 15.927 & 15.869 \\
\hline 0.011 & 0.011 & 0.008 & 0.020 & 0.008 & 0.015 & 0.008 & & & & & & & \\
\hline 0.090 & 0.102 & 0.096 & 0.165 & 0.110 & 0.115 & 0.092 & 0.086 & 0.069 & 0.094 & 0.040 & 0.120 & 0.057 & 0.101 \\
\hline & 0.003 & 0.003 & 0.003 & & 0.005 & 0.003 & & & & & & & \\
\hline 0.054 & 0.068 & 0.049 & 0.029 & 0.025 & 0.059 & 0.046 & & 0.075 & 0.029 & 0.050 & 0.050 & 0.066 & 0.059 \\
\hline 2.951 & 2.711 & 2.767 & 2.122 & 2.723 & 2.477 & 2.766 & 2.890 & 2.772 & 1.787 & 3.619 & 2.347 & 3.163 & 2.391 \\
\hline 1.076 & 1.305 & 1.217 & 1.861 & 1.365 & 1.514 & 1.264 & 0.991 & 1.181 & 2.247 & 0.355 & 1.644 & 0.757 & 1.626 \\
\hline & 0.002 & & 0.002 & 0.002 & 0.005 & 0.005 & & & & & & & 0.012 \\
\hline 0.004 & 0.006 & 0.007 & 0.006 & & 0.007 & 0.006 & & & & & & & \\
\hline 4.186 & 4.208 & 4.147 & 4.208 & 4.233 & 4.197 & 4.190 & 3.967 & 4.096 & 4.157 & 4.065 & 4.161 & 4.043 & 4.189 \\
\hline 20.028 & 20.013 & 19.981 & 19.990 & 20.021 & 20.016 & 20.031 & 19.871 & 20.000 & 20.047 & 20.009 & 20.034 & 19.970 & 20.058 \\
\hline 73.3 & 67.5 & 69.5 & 53.2 & 66.6 & 62.0 & 68.6 & 74.5 & 70.1 & 44.3 & 91.1 & 58.8 & 80.7 & 59.3 \\
\hline
\end{tabular}


Table 7. Composition of selected plagioclase groundmass crystals.

\begin{tabular}{|c|c|c|c|c|c|c|c|c|}
\hline \multirow[b]{2}{*}{ Component } & \multicolumn{8}{|c|}{$\begin{array}{c}\text { Sample } \\
\text { (interval in } \mathrm{cm} \text { ) }\end{array}$} \\
\hline & $\begin{array}{c}483 \mathrm{~B}-20-2, \\
16-21\end{array}$ & $\begin{array}{c}483 \mathrm{~B}-20-2, \\
16-21\end{array}$ & $\begin{array}{c}483 \mathrm{~B}-20-2 \\
37-42\end{array}$ & $\begin{array}{c}483 \mathrm{~B}-20-2 \\
50-59\end{array}$ & $\begin{array}{c}483 \mathrm{~B}-20-2 \\
50-59\end{array}$ & $\begin{array}{c}4838-20-2 \\
50-59\end{array}$ & $\begin{array}{c}483 \mathrm{~B}-20-2 \\
50-59\end{array}$ & $\begin{array}{c}483 B-27-1, \\
12-18\end{array}$ \\
\hline \multicolumn{9}{|c|}{ Major Oxides (wt.\%) } \\
\hline $\mathrm{SiO}_{2}$ & 53.84 & 56.29 & 52.77 & 56.71 & 52.72 & 54.19 & 57.24 & 52.39 \\
\hline $\mathrm{Al}_{2} \mathrm{O}_{3}$ & 29.03 & 27.07 & 29.59 & 27.47 & 29.38 & 28.19 & 27.04 & 29.61 \\
\hline $\mathrm{FeO}^{* a ̆}$ & 0.78 & 0.77 & 0.81 & 1.05 & 1.10 & 0.83 & 0.79 & 0.59 \\
\hline $\mathrm{MgO}$ & 0.22 & & 0.27 & 0.05 & 0.35 & 0.17 & 0.08 & 0.26 \\
\hline $\mathrm{CaO}$ & 11.86 & 9.79 & 12.73 & 9.90 & 12.63 & 12.15 & 9.63 & 13.08 \\
\hline $\mathrm{Na}_{2} \mathrm{O}$ & 4.67 & 8.84 & 4.32 & 5.95 & 4.18 & 4.47 & 6.17 & 4.10 \\
\hline $\mathrm{K}_{2} \mathrm{O}$ & & & 0.07 & 0.07 & & & 0.09 & \\
\hline Total & 100.40 & 99.76 & 100.56 & 101.20 & 100.34 & 100.73 & 101.04 & 100.04 \\
\hline \multicolumn{9}{|c|}{ Cation Proportions $^{\mathrm{b}}$} \\
\hline $\mathrm{Si}$ & 9.721 & 10.163 & 9.550 & 10.117 & 9.565 & 9.754 & 10.209 & 9.525 \\
\hline Al & 6.179 & 5.761 & 6.313 & 5.775 & 6.281 & 6.133 & 5.683 & 6.346 \\
\hline$\Sigma$ & 15.900 & 15.924 & 15.863 & 15.892 & 15.846 & 15.887 & 15.892 & 15.871 \\
\hline $\mathrm{Fe}$ & 0.117 & 0.116 & 0.123 & 0.156 & 0.166 & 0.126 & 0.118 & 0.090 \\
\hline $\mathrm{Mg}$ & 0.060 & & 0.072 & 0.022 & 0.094 & 0.046 & 0.022 & 0.071 \\
\hline $\mathrm{Ca}$ & 2.295 & 1.893 & 2.469 & 1.891 & 2.455 & 2.342 & 1.840 & 2.548 \\
\hline $\mathrm{Na}$ & 1.636 & 2.044 & 1.515 & 2.057 & 1.469 & 1.559 & 2.133 & 1.446 \\
\hline $\mathrm{K}$ & & & 0.016 & 0.012 & & & 0.021 & \\
\hline$\Sigma$ & 4.107 & 4.054 & 4.196 & 4.138 & 4.183 & 4.072 & 4.134 & 4.154 \\
\hline Total & 20.007 & 19.978 & 20.059 & 20.030 & 20.029 & 19.959 & 20.026 & 20.025 \\
\hline An mole $\%$ & 58.4 & $48: 1$ & 61.7 & 47.8 & 62.6 & 60.0 & 46.1 & 63.8 \\
\hline
\end{tabular}

Table 8. Composition of selected $\mathrm{Fe} / \mathrm{Ti}$-oxides.

\begin{tabular}{|c|c|c|c|c|}
\hline \multirow[b]{2}{*}{ Component } & \multicolumn{4}{|c|}{$\begin{array}{c}\text { Sample } \\
\text { (interval in } \mathrm{cm} \text { ) }\end{array}$} \\
\hline & $\begin{array}{l}483-22-2 \\
89-83\end{array}$ & $\begin{array}{c}483-22-2 \\
89-83\end{array}$ & $\begin{array}{l}483-22-2 \\
89-83\end{array}$ & $\begin{array}{c}485 \mathrm{~A}-30-4, \\
8-13\end{array}$ \\
\hline \multicolumn{5}{|c|}{ Major oxides (wt. \%) } \\
\hline $\begin{array}{l}\mathrm{SiO}_{2} \\
\mathrm{TiO}_{2} \\
\mathrm{Al}_{2} \mathrm{O}_{3} \\
\mathrm{FeO}^{* a} \\
\mathrm{FeO} \\
\mathrm{Fe}_{2} \mathrm{O}_{3} \\
\mathrm{MnO} \\
\mathrm{MgO} \\
\mathrm{CaO} \\
\mathrm{V}_{2} \mathrm{O}_{3}\end{array}$ & $\begin{array}{c}0.52 \\
22.93 \\
5.08 \\
68.34 \\
(51.13) \\
(19.13) \\
0.73 \\
0.65 \\
0.33 \\
0.20\end{array}$ & $\begin{array}{c}23.94 \\
5.16 \\
67.48 \\
(52.57) \\
(16.57) \\
0.48 \\
0.48 \\
0.17\end{array}$ & $\begin{array}{c}21.77 \\
6.67 \\
70.47 \\
(51.87) \\
(20.67) \\
0.42 \\
0.41 \\
0.11 \\
0.37\end{array}$ & $\begin{array}{c}0.55 \\
21.15 \\
1.99 \\
71.28 \\
(49.74) \\
(23.93) \\
0.82 \\
0.53\end{array}$ \\
\hline Total & $\begin{array}{r}98.78 \\
(100.7)\end{array}$ & $\begin{array}{c}97.99 \\
(99.37)\end{array}$ & $\begin{array}{c}100.22 \\
(101.92)\end{array}$ & $\begin{array}{c}96.32 \\
(98.71)\end{array}$ \\
\hline \multicolumn{5}{|c|}{ Cation proportions ${ }^{b}$} \\
\hline $\begin{array}{l}\mathrm{Si} \\
\mathrm{Al} \\
\mathrm{Ti} \\
\mathrm{Fe}^{2+} \\
\mathrm{Fe}^{3+} \\
\mathrm{Mn} \\
\mathrm{Mg} \\
\mathrm{Ca} \\
\mathrm{V}\end{array}$ & $\begin{array}{r}0.187 \\
2.157 \\
6.211 \\
15.403 \\
5.196 \\
0.223 \\
0.349 \\
0.127 \\
0.058\end{array}$ & $\begin{array}{r}2.230 \\
6.601 \\
16.119 \\
4.572 \\
0.149 \\
0.262 \\
0.067\end{array}$ & $\begin{array}{r}2.788 \\
5.807 \\
15.386 \\
5.517 \\
0.126 \\
0.217 \\
0.042 \\
0.105\end{array}$ & $\begin{array}{r}0.207 \\
0.881 \\
5.972 \\
15.621 \\
6.762 \\
0.261 \\
0.297\end{array}$ \\
\hline Total & 29.911 & 30.0 & 29.988 & 30.001 \\
\hline
\end{tabular}

Note: Recalculated values shown in parentheses.

${ }^{\mathrm{a}} \mathrm{FeO}^{*}$ represents total iron as $\mathrm{FeO}$.

b Proportions shown on a basis of 40 oxygen atoms. 
Table 9. Selected glass compositions.

\begin{tabular}{|c|c|c|c|c|c|c|c|}
\hline \multirow[b]{2}{*}{$\begin{array}{l}\text { Major Oxides } \\
(w t, \%)\end{array}$} & \multicolumn{7}{|c|}{$\begin{array}{c}\text { Sample } \\
\text { (interval in } \mathrm{cm} \text { ) }\end{array}$} \\
\hline & $\begin{array}{c}483-21-3 \\
6-9^{\mathrm{a}}\end{array}$ & $\begin{array}{c}483-21-3 . \\
6-9\end{array}$ & $\begin{array}{c}483-21-3 \\
6-9\end{array}$ & $\begin{array}{c}483 B-22-1 \\
26-32\end{array}$ & $\underset{77-82}{483 \mathrm{~B}-22-2}$ & $\begin{array}{c}483 \mathrm{~B}-30-3, \\
13-16\end{array}$ & $\begin{array}{c}\text { 483B-32-1, } \\
1-6\end{array}$ \\
\hline $\mathrm{SiO}_{2}$ & 50.51 & 50.10 & 51.69 & 50.47 & 51.95 & 50.24 & 50.79 \\
\hline $\mathrm{TiO}_{2}$ & 2.04 & 2.00 & 2.11 & 1.94 & 1.90 & 1.86 & 1.73 \\
\hline $\mathrm{Al}_{2} \mathrm{O}_{3}$ & 14.35 & 13.91 & 14.07 & 14.00 & 13.38 & 13.98 & 14.35 \\
\hline $\mathrm{FeO} * \mathrm{~b}^{\prime}$ & 11.51 & 11.40 & 12.18 & 11.47 & 11.43 & 11.37 & 10.48 \\
\hline $\mathrm{MnO}$ & - & 0.17 & - & 0.13 & 0.23 & - & - \\
\hline $\mathrm{MgO}$ & 4.39 & 7.04 & 6.90 & 7.11 & 6.45 & 7.15 & 7.62 \\
\hline $\mathrm{CaO}$ & 12.60 & 11.22 & 11.19 & 11.37 & 10.86 & 11.39 & 11.96 \\
\hline $\mathrm{Na}_{2} \mathrm{O}$ & 2.58 & 2.85 & 0.67 & 2.91 & 2,72 & 2.63 & 2.85 \\
\hline $\mathrm{K}_{2} \mathrm{O}$ & 0.12 & 0.08 & 0.08 & 0.09 & 0.07 & 0.08 & 0.12 \\
\hline $\mathrm{P}_{2} \mathrm{O}_{5}$ & 0.14 & 0.20 & 0.14 & 0.17 & - & - & 0.11 \\
\hline $\mathrm{SO}_{3}$ & 0.45 & 0.55 & 0.53 & 0.48 & - & 0.29 & 0.47 \\
\hline Total & 98.70 & 99.53 & 99.57 & 100.16 & 98.99 & 99.00 & 100.48 \\
\hline
\end{tabular}

a Glass inclusion in olivine.

${ }^{b} \mathrm{FeO}^{*}$ represents total iron as $\mathrm{FeO}$.

Table 10. Average mineral and glass compositions for selected basalts from Holes 483 and 483B.

\begin{tabular}{|c|c|c|c|c|c|c|c|c|c|c|c|}
\hline \multirow[b]{3}{*}{$\begin{array}{l}\text { Sample } \\
\text { (interval in } \mathrm{cm} \text { ) }\end{array}$} & \multicolumn{7}{|c|}{ Phenocrysts } & \multicolumn{4}{|c|}{ Groundmass } \\
\hline & \multicolumn{2}{|c|}{ Olivine } & \multicolumn{3}{|c|}{ Clinopyroxene } & \multicolumn{2}{|c|}{ Plagioclase } & \multicolumn{2}{|c|}{ Clinopyroxene } & \multirow{2}{*}{$\frac{\text { Plagioclase }}{\begin{array}{c}\text { An } \\
(\text { mole } \%)^{\mathrm{a}}\end{array}}$} & \multirow{2}{*}{$\begin{array}{c}\text { Glass } \\
\text { Mg No. }^{a}\end{array}$} \\
\hline & $\begin{array}{l}\text { Crystal } \\
\text { Type }\end{array}$ & $\mathrm{Mg} \mathrm{No}{ }^{\mathrm{a}}$ & $\begin{array}{l}\text { Crystal } \\
\text { Type }\end{array}$ & $\mathrm{Mg} \mathrm{No}^{\mathrm{a}}$ & $\mathrm{Ca}: \mathrm{Mg}: \mathrm{Fe}$ & $\begin{array}{l}\text { Crystal } \\
\text { Type }\end{array}$ & $\underset{(\mathrm{mole} \%)^{\mathrm{a}}}{\operatorname{An}}$ & Mg No. ${ }^{a}$ & $\mathrm{Ca}: \mathrm{Mg}: \mathrm{Fe}$ & & \\
\hline Hole 483 & & & & & & & & & & & \\
\hline $21-3,6-9$ & MP & $81.3(10)$ & $\mathrm{Gl}$ & $82.8(4)$ & $37: 52: 11$ & $\left\{\begin{array}{c}\mathrm{P} \\
\mathrm{MP}\end{array}\right.$ & $\left\{\begin{array}{l}82.6(12) \\
65.0(6)\end{array}\right.$ & - & - & - & $52.4(6)$ \\
\hline $22-2,85-88$ & $\mathrm{P}$ & $83.3(7)$ & $\mathrm{P}$ & $85.6(6)$ & $41: 51: 8$ & $\left\{\begin{array}{c}\mathrm{P} \\
\mathrm{MP}\end{array}\right.$ & $\left\{\begin{array}{l}83.0(21) \\
62.7(1)\end{array}\right.$ & - & - & $71.4(3)$ & - \\
\hline $26-1,39-40$ & - & - & - & - & - & P & $75.4(2)$ & - & - & - & - \\
\hline Hole 483B & & & & & & & $\cdot$ & & & & \\
\hline $\begin{array}{l}20-2,16-21 \\
20-2,37-42\end{array}$ & - & - & $\begin{array}{l}\text { MP } \\
\text { MP }\end{array}$ & $\begin{array}{l}86.9(4) \\
87.1(5)\end{array}$ & $\begin{array}{c}42: 50: 8 \\
42: 51: 7\end{array}$ & $\begin{array}{l}\mathrm{P} \\
\mathrm{P}\end{array}$ & $\begin{array}{l}87.9(21) \\
76.2(10)\end{array}$ & $\begin{array}{l}70.6(3) \\
81.5(11)\end{array}$ & $\begin{array}{l}40: 42: 18 \\
31: 56: 13\end{array}$ & $\begin{array}{l}64.1(13) \\
63.2(7)\end{array}$ & - \\
\hline $20-2,50-59$ & - & - & GL, MP & $85.6(9)$ & $42: 50: 8$ & $\left\{\begin{array}{l}\mathrm{M} \\
\mathrm{p}\end{array}\right.$ & $\left\{\begin{array}{l}89.2(6) \\
81.3(17)\end{array}\right.$ & $79.0(4)$ & $38: 47: 15$ & $62.1(5)$ & - \\
\hline $20-2,50-59$ & - & - & $\begin{array}{c}\text { M } \\
\text { MP }\end{array}$ & $\begin{array}{l}84.1(7) \\
84.7(7)\end{array}$ & $\begin{array}{l}40: 50: 10 \\
41: 50: 9\end{array}$ & $\mathrm{P}$ & $80.3(22)$ & 74.0 (3) & $35: 48: 17$ & $62.9(7)$ & - \\
\hline $22-1,26-32$ & $\mathrm{P}$ & $81.6(7)$ & $\mathrm{MP}, \mathrm{GL}$ & 84.0 (14) & $40: 50: 10$ & $\mathrm{P}$ & $78.2(14)$ & $\bar{x}$ & $=$ & - & $52.5(7)$ \\
\hline $22-2,63-67$ & - & - & $\mathrm{MP}, \mathrm{GL}$ & 83.1 (15) & $40: 50: 10$ & $\mathrm{P}$ & $76.2(18)$ & $80.7(3)$ & $31: 56: 13$ & 64.7 (3) & - \\
\hline $25-2,39-45$ & - & - & $\mathrm{MP}, \mathrm{GL}$ & $84.7(23)$ & $40: 50: 9$ & $\mathrm{P}$ & 75.8 (13) & - & - & $69.0(4)$ & - \\
\hline $27-1,12-18$ & & - & MP, GL & $83.1(4)$ & $41: 49: 10$ & $\mathrm{P}$ & $80.8(14)$ & $72.5(5)$ & $39: 44: 17$ & $69.3(3)$ & - \\
\hline $30-3,13-16$ & ? & $\begin{array}{l}86.2(4) \\
82.9(6)\end{array}$ & $\mathrm{MP}, \mathrm{GL}$ & $84.2(8)$ & $42: 49: 9$ & $\left\{\begin{array}{c}P \\
G L\end{array}\right.$ & $\left\{\begin{array}{l}88.6(9) \\
67.6(1)\end{array}\right.$ & - & - & $67.6(3)$ & $53.8(7)$ \\
\hline $30-3,18-22$ & $\mathrm{P}$ & $84.5(2)$ & - & - & - & $\mathrm{P}$ & 82.1 (3) & - & - & - & - \\
\hline $32-1,1-6$ & MP, P & $84.5(11)$ & $\mathrm{MP}, \mathrm{GL}$ & $84.9(12)$ & $36: 54: 10$ & $P$ & 86.1 (23) & - & - & - & $56.9(10)$ \\
\hline $39-1,26-32$ & - & - & $\mathrm{MP}, \mathrm{GL}$ & $77.7(6)$ & $42: 45: 13$ & $\left\{\begin{array}{l}\mathrm{M} \\
\mathrm{GL}\end{array}\right.$ & $\left\{\begin{array}{l}91.7(42) \\
62.6(1)\end{array}\right.$ & $76.0(6)$ & $38: 47: 15$ & 70.1 (4) & - \\
\hline
\end{tabular}

Note: $\mathrm{M}=$ megacryst; $\mathrm{P}=$ phenocryst; $\mathrm{MP}=$ microphenocryst; $\mathrm{GL}=\mathrm{cpx}$-pl glomerocryst.

${ }^{a}$ Number of analyses in parentheses. 


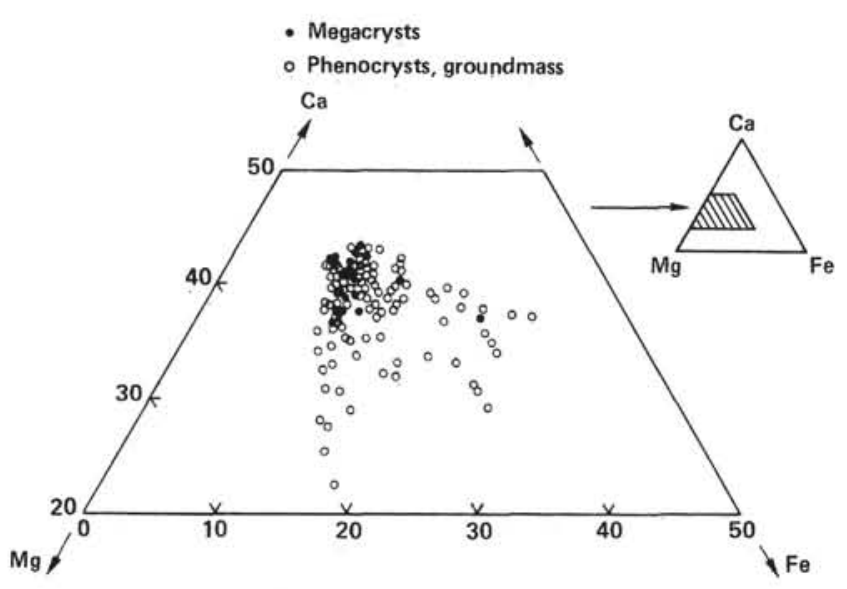

Figure 10. Quadrilateral diagram showing compositions of clinopyroxene megacrysts, phenocrysts, and microphenocrysts in Leg 65 basalts.

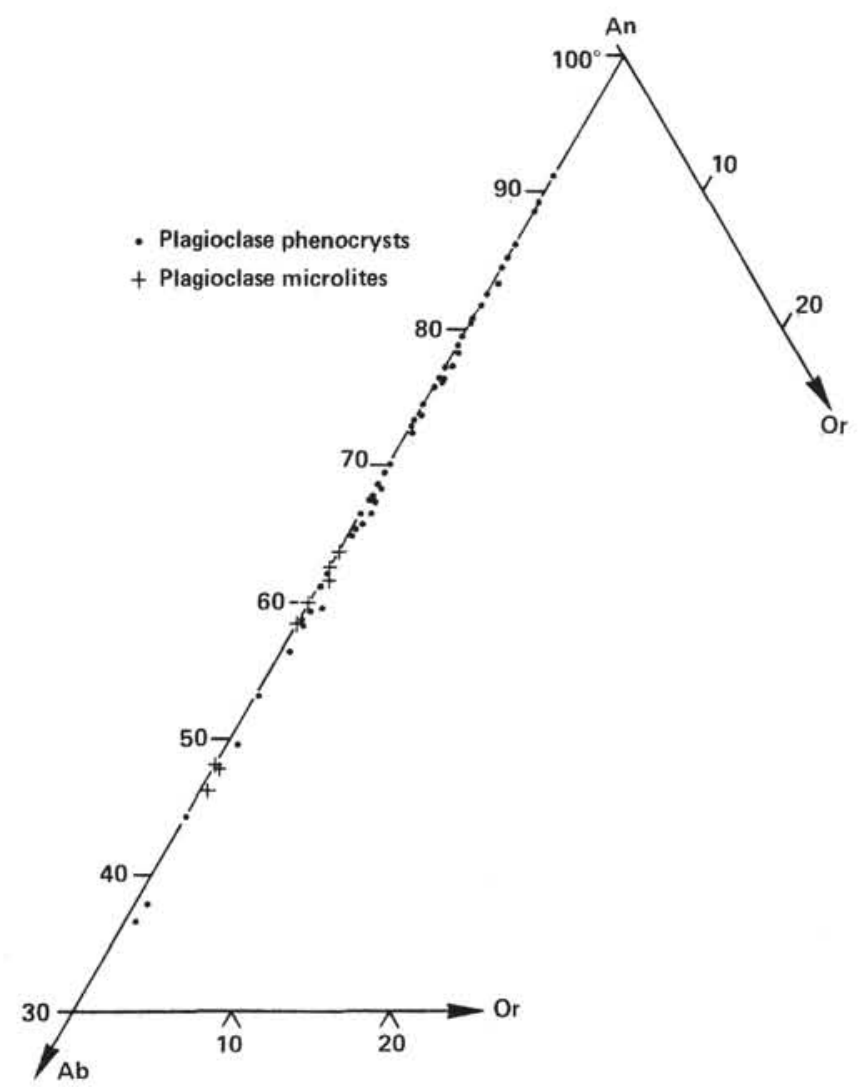

Figure 11. Ternary plot showing selected plagioclase compositions for Leg 65 basalts. 

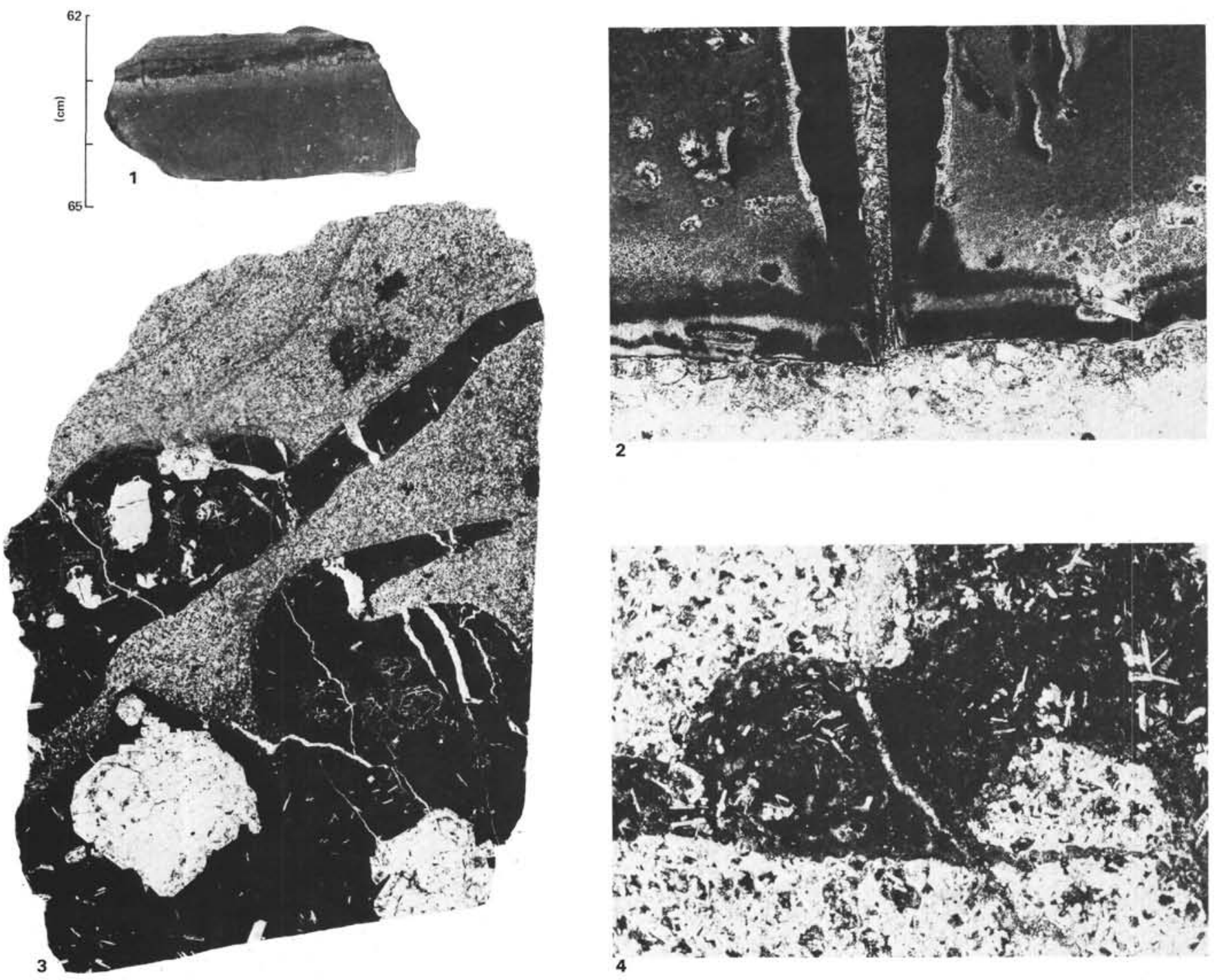

Plate 1. Massive basalts recovered on Leg 65. 1. Sample 483B-20-2, 62-65 cm; thin layer of sandstone adhering to the devitrified base of a massive lava flow (Lithologic Unit 6) (see also Fig. 2.). 2. Sample 483B-20-2, 62-65 cm; basal contact of massive sheet flow(?) (Unit 6) against underlying siltstone (light-colored); glass shows dark alteration against silt and on both sides of straight fracture filled with smectite; glass rinds on massive flows are thinner than on pillows (width of photomicrograph, $5 \mathrm{~mm}$ ). 3. Sample 485A-38-2, 5-10 cm; cross section through top of deepest massive (intrusive?) basalt drilled in Hole 485A (Lithologic Unit 8) showing devitrified glass stringers in siltstone (width of photograph, 2 $\mathrm{mm}$ ). 4. Sample 483-16-2, 64-70 cm; fine-grained basalt intruding (self-intruding) medium-grained, massive basalt (Unit 3 ) (width of photomicrograph, $5 \mathrm{~mm}$ ). 

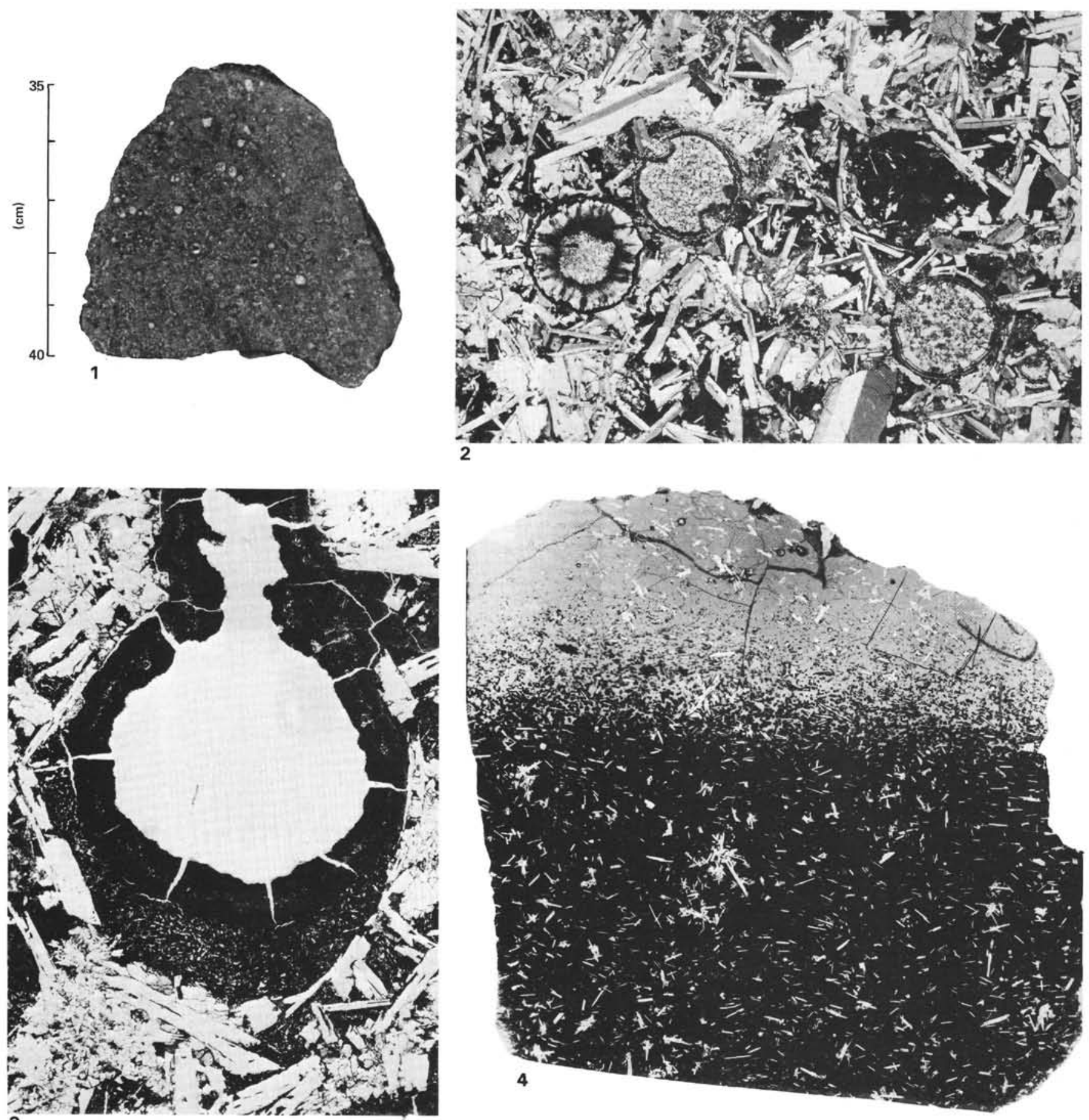

Plate 2. Pillow basalts recovered on Leg 65. 1. Sample 483B-18-2, 35-40 cm; highly vesicular basalt 1.5 meters below top of 3.5 -meter-thick massive flow (Lithologic Unit 6) (see also Fig. 3). 2. Sample 483B-26-2, 42-47 cm; massive, vesicular basalt with a coarse-grained, subophitic to intersertal groundmass (Lithologic Unit 8); vesicles to right and center lined with carbonate and filled with smectite; vesicle on left filled with chlorite(?); vesicle to the upper right is a filled segregation vesicle (width of photomicrograph, $5 \mathrm{~mm}$ ). 3 . Sample $483 \mathrm{~B}-18-2,18-22 \mathrm{~cm}$; partially filled segregation vesicle subsequently lined with smectite(?) showing contraction cracks; note plagioclase laths aligned tangential to vesicle (see Fig. 1) (width of photomicrograph, $5 \mathrm{~mm}$ ). 4. Sample 482D-11-1, 24-28 cm; cross section through thick, fresh glassy margin of porphyritic pillow lava ( $50 \mathrm{~cm}$ thick) (see also Plate 4, Fig. 1 for photomicrograph of olivine and plagioclase microphenocrysts) (width of photomicrograph, $2 \mathrm{~cm}$ ). 

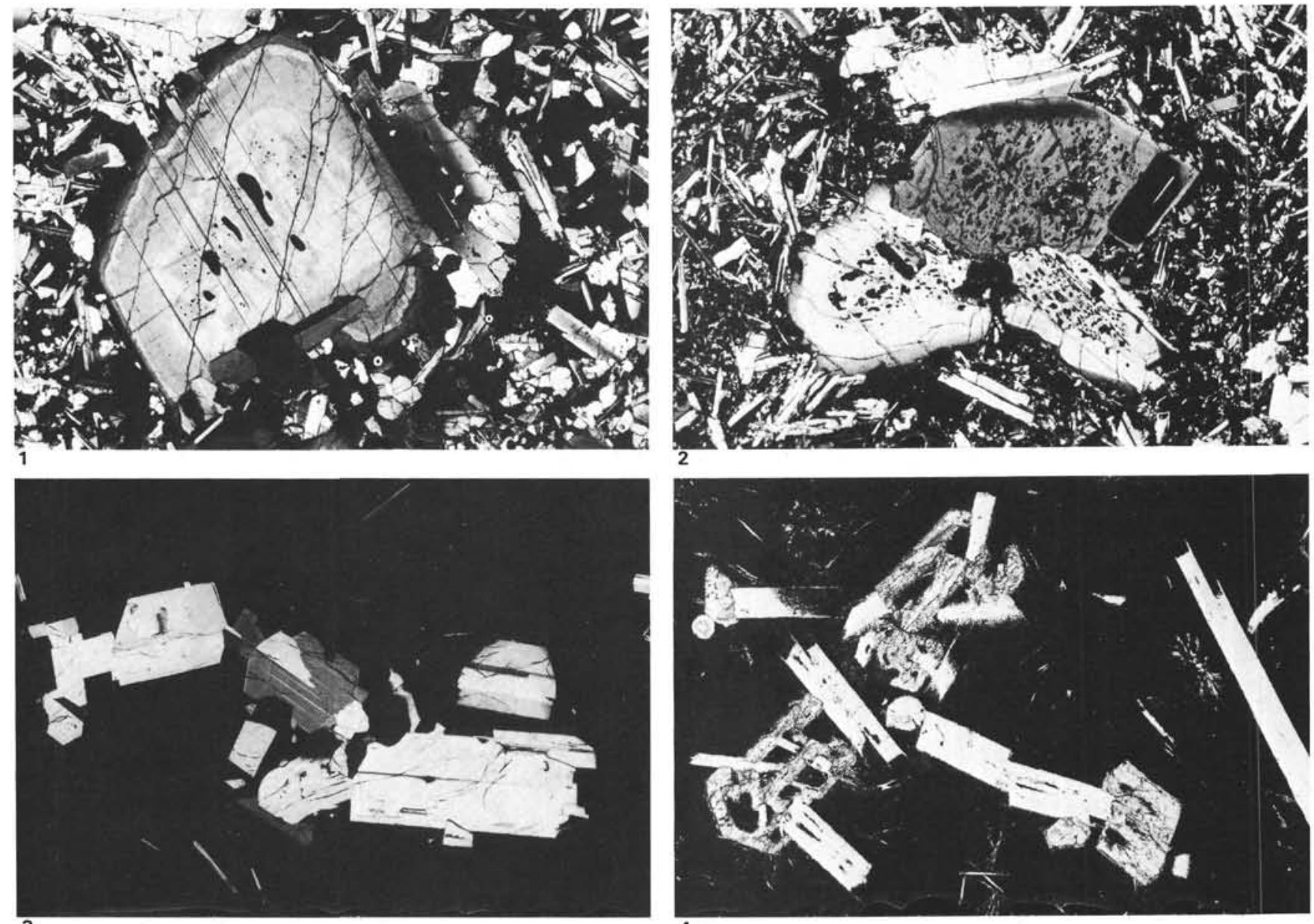

4

Plate 3. Plagioclase phenocrysts. 1. Sample 483B-7-1, 7-12 cm; plagioclase megacryst in massive flow (Lithologic Unit 3) showing inclusion-rich, partially resorbed core (light gray), an oscillatory zoned mantle, and a dark outer rim separated from the mantle by a sharp compositional break (width of photomicrograph, $5 \mathrm{~mm}$ ). 2. Sample 483-23-1, 10-16 cm; glomerocryst in pillow basalt (Unit 6) consisting of three partially resorbed plagioclase xenocrysts with numerous glass inclusions and two subhedral plagioclase phenocrysts (width of photomicrograph, $5 \mathrm{~mm}$ ). 3 . Sample 483-21-1, 49-55 cm; euhedral to subhedral clot of regularly zoned plagioclase phenocrysts in tachylitic matrix of pillow basalt (Unit 6) (width of photomicrograph, $5 \mathrm{~mm}$ ). 4. Sample 485A-36-3, 65-69 cm; clot of skeletal olivine and weakly skeletal plagioclase microphenocrysts in finegrained pillow basalt(?) (Unit 7) with a tachylitic groundmass containing skeletal plagioclase microlites (width of photomicrograph, $2 \mathrm{~mm}$ ). 

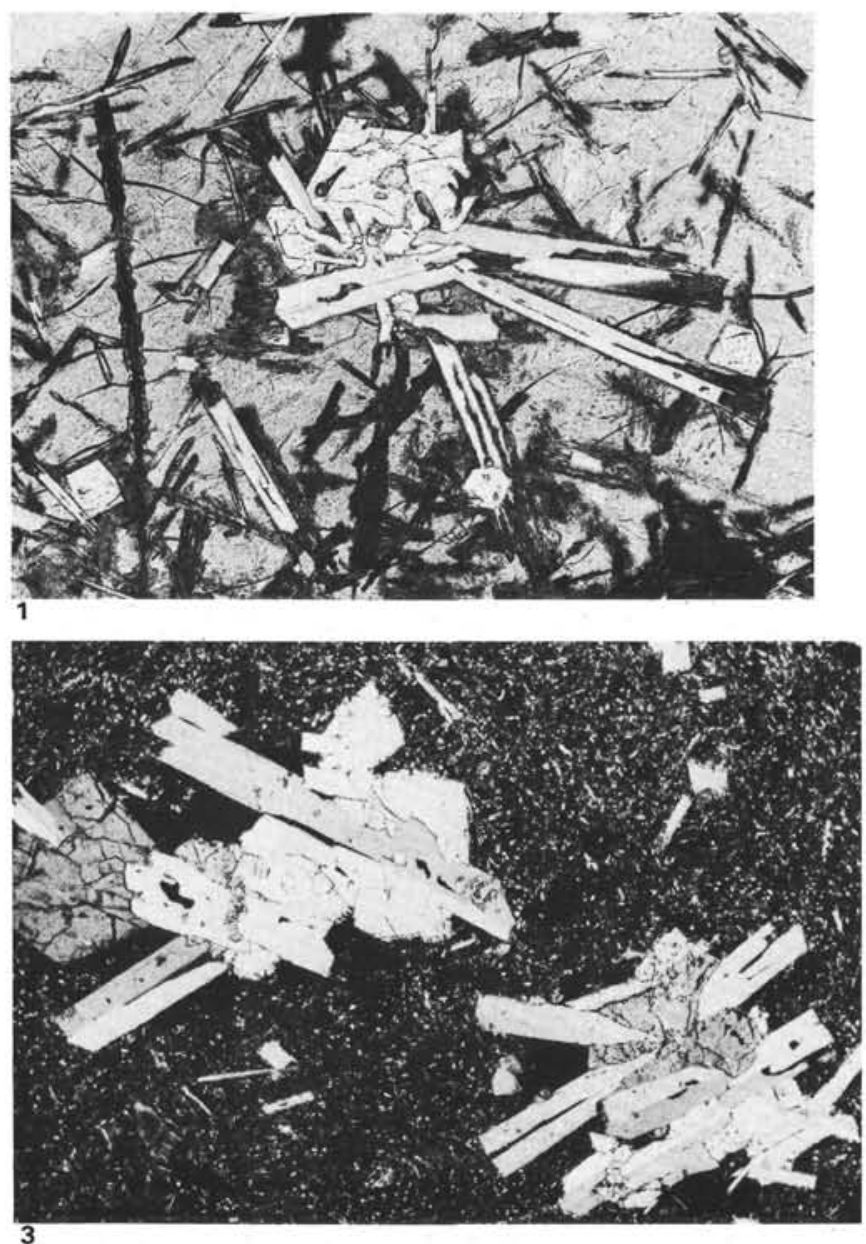
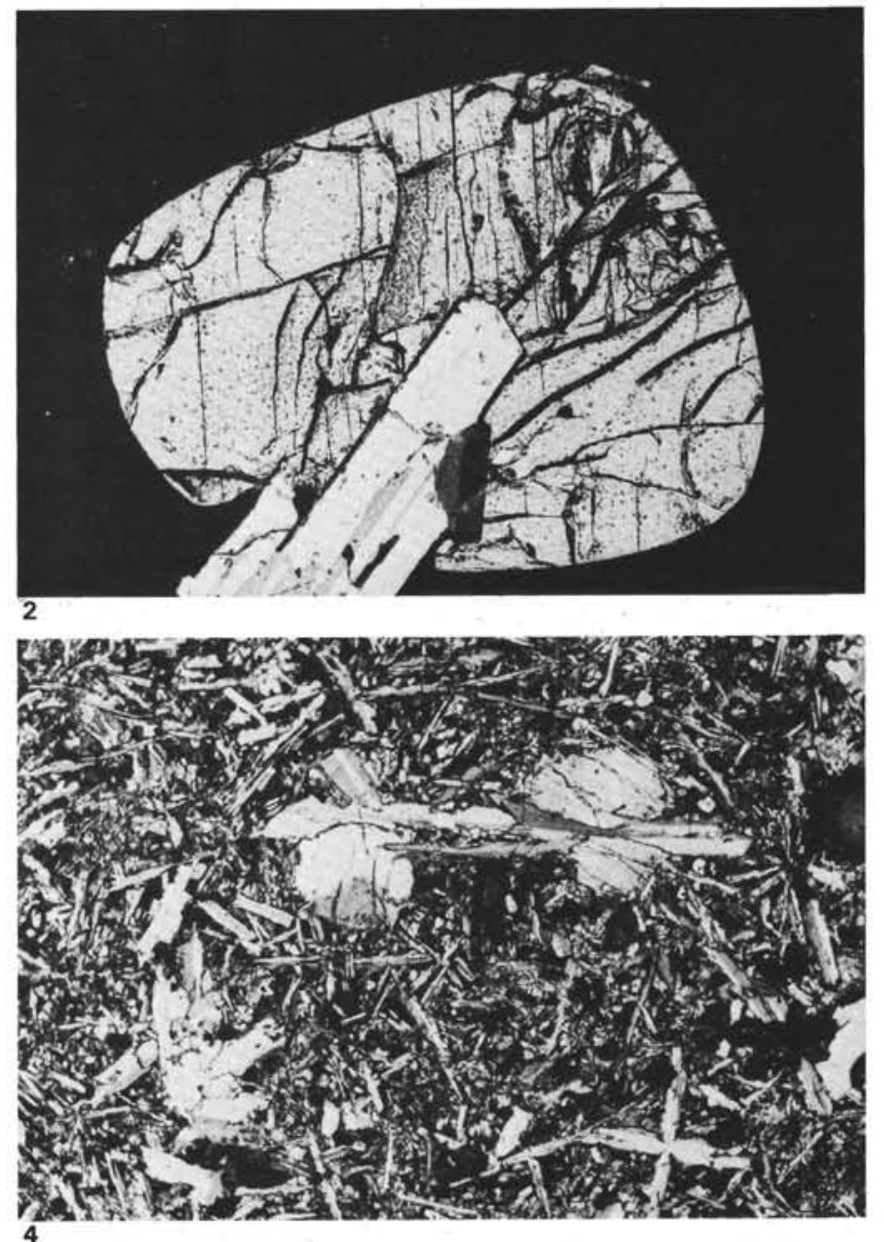

4

Plate 4. Phenocrysts and clots. 1. Sample 482D-11-1, 24-28 cm; clot of skeletal plagioclase and olivine microphenocrysts in a matrix of fresh sideromelane from the margin of a pillow; microphenocrysts show minor terminal in situ growth (width of photomicrograph, $2 \mathrm{~mm}$ ). 2 . Sample 483-22-2, 68-72 cm; partially resorbed clinopyroxene megacryst enclosing euhedral plagioclase phenocrysts in a tachylitic pillow margin (Lithologic Unit 6) (width of photomicrograph, $5 \mathrm{~mm}$ ). 3. Sample 483-22-2, 77-82 cm; clot of subhedral to euhedral clinopyroxene and plagioclase crystals in a tachylitic pillow margin (Lithologic Unit 6) (width of photomicrograph, $5 \mathrm{~mm}$ ). 4. Sample 483B-29-1, 55-57 cm; clot of strained anhedral clinopyroxene and plagioclase in an intersertal pillow basalt matrix (Lithologic Unit 9) (width of photomicrograph $5 \mathrm{~mm}$ ). 